\title{
Cristo desnudo en la cruz: el problemático comienzo de dicha representación*
}

\author{
John Jairo Osorio Arango**
}

Recibido: 11 de febrero de 2015 - Revisado: 14 de abril de 2015 -

Aprobado: 14 de agosto de 2015

Para nada fácil que las primeras comunidades cristianas llegaran con resolución a la representación del patíbulo en el cual fuera (aparentemente) derrotado el Hijo de Dios. El tema de la ejecución (condenación y maldición) sumado al problema plástico (proclive a la idolatría), parecen explicar la tardanza de llegar a ese primer intento de un crucificado que encontraremos solo hasta el siglo IV-V. Poco después se da la respuesta teológica que pretendía superar la problemática herejía que negaba o separaba la condición divina de la humana y otro tanto después el papel devocional, espiritual y (si se lo quiere) litúrgico de dichas representaciones. Pero mucho antes del Renacimiento Humanista del siglo XV ya el franciscanismo del siglo XIII habría hecho de esta temática, con un particular velo de pureza, una feliz y primera gramática del todo significativa y tanto más única para la revelación así como para esta estética.

Palabras clave: desnudo, desnudez, estética-cristiana, plástica-cristiana, historiadel-arte-cristiano, piel, censura.

\footnotetext{
* $\quad$ Artículo de investigación que recoge los aportes con que obtuvo la Licenciatura en Historia y Bienes Culturales de la Iglesia por la Pontificia Universidad Gregoriana de Roma en el año 2011.

** Licenciado en Historia y Bienes Culturales de la Iglesia por la Pontificia Universidad Gregoriana de Roma en Italia, 2011. Profesor asociado a la Escuela de Teología, Filosofía y Humanidades de la Universidad Pontificia Bolivariana de Medellín en Colombia, en las cátedras de Arte Cristiano, Historia del Arte y Jesús en el Cine. Dirección postal: carrera 75DA\# 1 sur 140, interior 301, Medellín, Colombia, correo electrónico: osorioarango@gmail.com
} 


\title{
Christ naked on the cross: the problematic beginning of such representation*
}

\author{
John Jairo Osorio Arango**
}

Not easy at all for the first Christian communities to arrive resolutely to the representation of the gallows in which was (apparently) defeated the Son of God. The topic of the execution (condemnation and curse) in addition to the plastic problem (prone to idolatry), seem to explain the delay to arrive to that first attempt of a crucified which we only find until the IV-V century. Shortly after, comes the theological response that sought to overcome the heresy problems that denied or separated the divine from the human condition and afterwards the devotional, spiritual, and (if so desired) liturgical role of such representations. But long before the Renaissance Humanism of the XV century the Franciscanism of the XIII century already would have made of this topic, with a particular veil of purity, one happy and first grammar of all significant and thus more unique to the revelation as well as for this aesthetics.

Keywords: Nude, nudity, Christian aesthetics, Christian visual arts, Christian art history, skin, censorship.

\footnotetext{
Research article that collects the contributions with which he earned the Degree in History and Cultural Properties of the Church in the Pontifical Gregorian University of Rome in the year 2011.

** Graduate in History and Cultural Properties of the Church by the Pontifical Gregorian University of Rome, Italy 2011. Associate Professor in the School of Theology, Philosophy and Humanities in the Pontifical Bolivarian University of Medellin, Colombia, in the chairs of Christian Art, History of Art and Jesus in the Movies, Postal address: carrera 75DA \# 1 sur 140, interior 301, Medellín, Colombia, e-mail: osorioarango@gmail.com
} 


\section{Le Christ nu sur la croix: le problématique début de cette représentation*}

John Jairo Osorio Arango**

Ce ne fut pas simple que les premières communautés chrétiennes soient parvenues avec résolution à la représentation de l'échafaud sur lequel fût (apparemment) abattu le Fils de Dieu. Le thème de l'exécution (condamnation et malédiction) ajouté au problème plastique (enclin à l'idolâtrie), semble expliquer le retard pour arriver à ce premier essai d'un crucifié que l'on ne retrouvera qu'au IV-V siècle. Peu après l'on trouve la réponse théologique qui prétendait surmonter la problématique hérésie qui niait ou séparait la condition divine de la condition humaine et ensuite le rôle de dévotion, spirituel et (si l'on veut) liturgique de ces représentations. Mais bien avant la Renaissance Humaniste du XV siècle, déjà le franciscanisme du XIII siècle aurait fait de cette thématique, avec un voile particulier de pureté, une joyeuse et première grammaire totalement significative et tellement unique pour la révélation comme pour cette esthétique.

Mots clés: $\mathrm{Nu}$, nudité, esthétique-chrétienne, plastique-chrétienne, histoire-del'art- chrétien, peau, censure.

Article de recherche qui recueille les apports avec lesquels il a obtenu la Licence en Histoire y Biens Culturels de l'Église par I'Université Gregoriana de Rome en 2011.

** Titulaire d'une maîtrise en Histoire y Biens Culturels de l'Église par I'Université Gregoriana de Rome en Italie, 2011. Professeur associé a l'école de Théologie, Philosophie et Sciences Humaines de I'Université Pontificia Bolivariana de Medellin en Colombie, dans les cours d'Art Chrétien, Histoire de I'Art et Jésus au Cinéma. Adresse postale: carrera 75DA\# 1 sur 140, interior 301, Medellin, Colombie, e-mail: osorioarango@gmail.com 
Todas las artes son, pues, modos de comunicar la desnudez de la vivencia.

Escultura, por ejemplo, es desnudar un mármol, o un tronco de árbol del sobrante, para que quede desnudo el concepto o espíritu que animaba al artista. Arte es conseguir la desnudez del dios, para que todos comulguemos o lo tengamos en nosotros - presencia-. Uno altísimo, Miguel Ángel, lo expresó así: "Non [sic] e nessun concetto q'un marmo solo non circonscriva col suo soverchio".

(González, 1959, p. 29)

\section{Introducción}

Es tardío el tema iconográfico del Cristo crucificado. Nunca antes del siglo V fue representado el patíbulo de la cruz; inmediata fue en cambio la representación de la desnudez de este ajusticiado. Por otro lado, desde su aparición y a lo largo de toda la vasta historia de arte cristiano, la desnudez del Crucificado aparece y desaparece, se oculta y desvela, confirmándose en esta oscilación lo que escribe Hans Belting (2007): “También cuando Cristo ha sido concebido como una figura enmascarada, de la cual se puede saber cuanto se puede ver, su imagen muestra lo que al mismo tiempo oculta" (p. 83)².

No son comunes ni frecuentes las representaciones en que aparece Cristo completamente desnudo en la cruz; sin embargo esta variante del Crucificado que poco se ha generalizado y que aparece como excepción en la historia del arte cristiano, nos permite entrar indagando por el polivalente concepto de la desnudez y la razón de esta intermitencia representativa.

En el tema de la crucifixión de Cristo, el aspecto de su desnudez plantea una variedad de interpretaciones que requieren del concurso de algunos factores de tipo histórico, cultural, antropológico, inclusive los teológicos y bíblicos, para captar objetivamente todo lo que incide y puede desentrañarse de cada concepto de desnudez. Lo que no puede pensarse de ninguna manera es que la desnudez del crucificado se conciba como una insensatez del arte. El tema de la desnudez, como lo hemos expuesto antes y lo seguiremos haciendo de continuo, no es un absurdo ni dentro ni fuera del pensamiento cristiano. Sucederá que encontraremos desaciertos, errores, pero nunca un despropósito.

1 Este filósofo cita el celebérrimo soneto 151: "Non ha l'ottimo artista alcun concetto/c'un marmo solo in sé non circonscriva/col suo superchio, e solo a quello arriva/la man che ubbidisce allintelletto"; traduce: "No tiene óptimo artista algún concepto/que el mármol solo en sí no circunscriba/con exceso, y a eso solo arriba/la mano que obedece el intelecto" (González, 1959, p. 29).

2 La máscara en la obra de $\mathrm{H}$. Belting tiene dos sentidos que conviene aclarar: primero en el contexto de la discusión teológica de los primeros siglos del cristianismo, cuando se está formando el Dogma de las naturalezas divina-humana de la persona de Cristo; de otro lado, dentro de la discusión antropológica (cf. Belting, 2007); y agrega: "las imágenes de Cristo no solo estuvieron sujetas a las solicitaciones excesivas de una contradictoria ontología del cuerpo, sino que encontraron también dificultades relativas a una historia del cuerpo" (p. 105). 
El arte cristiano ha implementado el lenguaje de la desnudez cuando ha sido inspirado por algo más que los contenidos teológicos o las corrientes espirituales que se lo permiten, así se trate de las fuentes bíblicas que la documentan o la historiografía que la defienda. Por poner un ejemplo, la Contrarreforma y, como lo veremos en su momento, los tratadistas del Cinquecento, impulsados por las directrices del Concilio de Trento, determinaron concretamente el papel que debía jugar la desnudez en los temas del arte cristiano, pero no es esta la única instancia ni este el único siglo que determinará la aparición o la desaparición de dicha posibilidad estética-plástica o si se quiere comunicativa.

\section{De la cruz al Crucificado}

El arte de las primeras comunidades cristianas, antes de la paz del siglo IV, no parece haber tenido otra preocupación más que la de cumplir con un reducido número de funciones precisas, aunque André Grabar persiste en la duda de que tales creaciones tuvieran algo de artístico (1967, pp. 23-24). A esto se agrega que los responsables de las primeras creaciones plásticas lograron conocer correctamente tanto los alcances como los límites -o riesgos-de la representación artística que legislaba celosamente el libro del Éxodo (20:4-5) ${ }^{3}$.

Pese a la tajante determinación, esta disposición, por prohibitiva que pareciese, conoció sin embargo algunas excepciones. Una, la más representativa en estrecha relación con este discurso, es la que el mismo Jesús toma en consideración, identificándose o auto-representándose en ella, hablando de su muerte y de la ostensión de su cuerpo en la cruz (Juan 3:14-15).

Sin embargo el tema de la serpiente de bronce que Moisés exaltó en el desierto como profecía-tipología de la cruz de $\mathrm{Cristo}^{4}$, no inspirará inmediatamente el imaginario cristiano aun cuando esta clase de lectura tipológica era tan típica para el Nuevo Testamento. También los Padres de la Iglesia sin promover directamente el tema de la cruz pero sabiendo ahuyentar de ella cualquier sombra de ofensa que pueda resultar escandalosa a los iniciados, utilizan ésta y otras más claves de lectura.

Cirilo de Jerusalén (ca. 315-386) afirma en una de sus catequesis: "que no nos dé vergüenza la cruz del Salvador, e incluso gloriémonos en ella"5; expresión que podríamos decir no escondía la verdad del patíbulo, y con ella tradujo en

3 En la misma línea prohibitiva del Pentateuco están: Ex. 34:14.17; Lv. 19:4; Dt. 4:15-18; 27:15; entre otras más.

4 El tema de la serpiente -una de las tipologías del Antiguo Testamento- inicia en el libro de los Números 21:8-9. La serpiente llegó a convertirse casi de inmediato en un objeto de culto -mirarla para sanarse, v. 8-; más tarde degeneró en un ídolo que Ezequías debió destruir: $2 \mathrm{Re}$. 18:4. Superando el conflicto del uso de las imágenes, el libro de la Sabiduría (16:5-7) recupera la memoria de la serpiente subrayando su aspecto salvifico: "quien la miraba se sanaba, no por ella, sino por ti, Salvador de todos".

5 Agrega además: "la pasión fue, pues, real: fue verdaderamente crucificado, y no nos avergonzamos de ello; fue crucificado y no lo negamos [...]. Puesto que la resurrección ha seguido a la cruz, no me da vergüenza proclamarla [...]. No te avergüences de confesar la cruz" (Cirilo de Jerusalén, De Christo crucifixo et sepulto, Catechesi 13,3.4.22.34.36, PG XXXIII, pp. 774, 775, 799, 814, 815). Téngase en cuenta además el Sermón 3 Güelferbitano de san Agustín (PLS II, 
lenguaje iconográfico no el instrumento de la muerte sino el sentido de triunfo y de victoria, es la crux invicta o trophæum Christi, por eso aparece decorada de piedras preciosas y embellecida de la mejor manera (figura 1) en algunas basílicas paleocristianas.

Como se deduce, del siglo III al siglo IV, el primer arte cristiano se limitó a representarlo todo dentro de la esfera del lenguaje simbólico en la misma línea que suele hacerlo el profuso material imaginario de la Sagrada Escritura, de donde proviene la mayor parte de la inspiración plástica.

Las primeras comunidades cristianas compartieron provisionalmente lo que encontraron útil del repertorio imaginario del mundo grecorromano en el que se empezaron a expandir. Muy rápidamente se creará un lenguaje propio, pero hasta entonces nada específico serviría para representar el tema de la crucifixión. Solo con alguna anterioridad a la paz constantiniana, año 313 d. C., aparecerá en las comunidades cristianas tímida y discretamente el signo de la cruz ${ }^{6}$. El más conocido ejemplo es el epígrafe de Rufina ${ }^{7}$ (figura 2), no posterior al siglo II, como testimonio de un creciente y sensible culto a la cruz, dado que el mismo Tertuliano (ca.160-ca. 220) en su Apologético se atreverá a llamar a los cristianos: "cruces religiosas" (Apologeticus XXXVII. PL I, 461; cf. Thoby, 1959, p. 16); algo más: "adorando nosotros cruces desnudas, vosotros las adoráis adornadas"8. Pero todavía estamos bastante lejos de los primeros intentos de representar el acontecimiento de la salvación que hasta entonces solo podrá hablarse de un uso tipológico 9 .

545-546), en que se ahuyenta el temor y la vergüenza que las primeras comunidades cristianas experimentaron ante la cruz de Jesús.

6 El signo de la cruz no es patrimonio único del cristianismo; era signo cósmico mucho antes de ser un instrumento de muerte y tanto más antes del valor salvífico que le otorgó la fe cristiana. Antes de la incursión del cristianismo en la cuenca del mediterráneo, una cruz indicaba la vida, la unión entre el mundo material y espiritual; incluso marcaba el territorio del sacro (cf. Grossi, 2006, pp. 1295- 1298; Giglioni, 2000, p. 7; Felle, 2000, p. 158).

7 La explícita cruz del epígrafe de PO ФINA EIPHNH (ICUR IV 9499) del hipogeo de Lucina en san Calixto, es una entre tantas: la de Gaud<e>ntia (ICUR III, 7619), Valerianus en el cementerio de Domitila (ICUR III 6958), en la catacumba de Novaciano (ICUR VII 20579), de Priscila que asocia la cruz y el ancla (ICUR IX 26022, 26070 y X, 26501) (cf. Carletti, 2009; Felle, 2000, p. 159).

8 "Noluistis nudas et incultas cruces consecrare" (Tertuliano, Apologeticus XVI. PL I, 369).

9 "El uso de expresar en imágenes lo que los primeros cristianos conocieron en dogmas [...] es solo en torno al $400 \mathrm{~d}$. C cuando el alto clero conoce los alcances de la iconografía, orienta sus representaciones para hacerla un instrumento eficaz de la fe pública y privada" (Grabar, 2003, p. 47). 


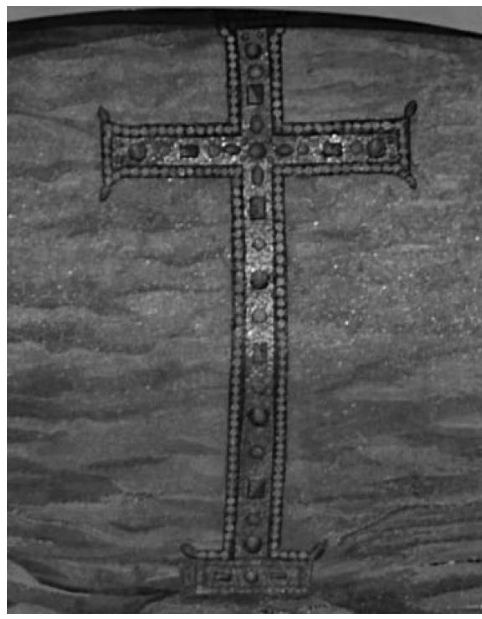

Figura 1. Basílica de santa Pudenziana. Cruz gemada, detalle del mosaico del ábside, 401 ca.

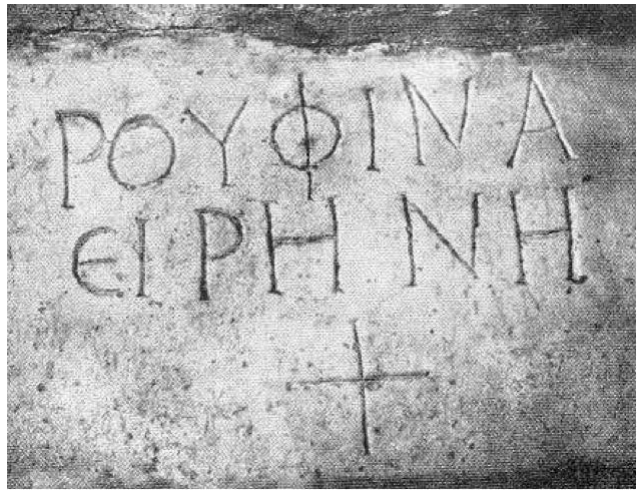

Figura 2. Epígrafe de PO ФINA EIPHNH (ICUR IV 9499), hipogeo de Lucina en san Calixto.

Si el primitivo aniconismo del Antiguo Testamento no fue inmediatamente superado por los autores del Nuevo Testamento, entonces, ¿qué hizo que dos religiones, en principio anicónicas, se dotaran en la misma época de un arte religioso?, ¿en qué momento preciso ocurre el paso a la representación artística?

Si es bien claro que entre los propósitos del arte y la mentalidad del cristianismo no existe ninguna contradicción ${ }^{10}$, no habría inicialmente ningún problema para representar concretamente el tema de la crucifixión, pero cuestiones como estas

10 Entre los estudiosos está A. Grabar (2003, p. 17), quien, desde el prefacio de su obra afirma que el rechazo a las imágenes -su ausencia en los primeros siglos- nunca se debe expressis verbis a una prohibición por parte de los teólogos, lo que nos priva de noticias acerca del estado espiritual y de las controversias en las comunidades anteriores del año 200 d.C. Otro es E. Kitzinger, quien sostiene que: "il cristianesimo in un primo momento fu avverso a immagini di qualsiasi tipo, rifiutandole non solo in quanto possibili fonti di idolatria, ma anche in quanto simbolo dello splendore e del lusso terreno" y agrega: "fu durante il II e il IV secolo che i cristiani iniziarono ad adattare l'arte classica ai loro scopi" (2005, pp. 3-5). 
se siguen discutiendo todavía hoy, considerando que son complejos los inicios del primer arte cristiano. Lo más acertado es pensar que a la incipiente y tímida aparición de la cruz le suceda luego la representación de la crucifixión ${ }^{11}$, porque como se dijo antes, la imagen soporta con mayor fuerza el contenido teológico; en esto se confirma lo que dice J. Plazaola:

Por razones intrínsecas al misterio de la encarnación y por necesidad natural del pueblo fiel, fue pasando del uso de los símbolos, en la mayoría de los casos comunes al judaísmo y al cristianismo, al de las figuras narrativas o anecdóticas, evocadoras de los hechos significativos de la vida de Jesús (2001, p. 107).

Ni siquiera la inventio crucis $^{12}$, que generó un notable impacto en la devoción y en la arquitectura cristiana, no impactó inmediatamente la iconografía de la crucifixión, se reforzó sí la idea de la crux invicta ${ }^{13}$, además de acelerar el fenómeno de la difusión de las reliquias de la Santa Cruz que perduró con demasiada fuerza hasta el Medioevo. Cruz y crucifixión mantendrán su sentido unívoco $^{14}$-al menos durante los primeros siglos- lo que hará esperar todavía más la representación del Crucificado.

\section{El inicio de esta iconografía}

En la tradición cristiana, la Sagrada Escritura y la iconografía se respaldan. Pero el caso de la predicación de Pablo, cuyo centro es el Mesías crucificado, "gloria suya"15, aunque fuera "escándalo para los judíos y locura para los griegos" (1 Cor. 1:22-23), paradójicamente no impulsó en los primeros siglos de la plástica cristiana un repertorio de imágenes de este Mesías ni de su cruz. ¿Qué impidió que este tema, tan neurálgico para la fe y la comprensión del mensaje cristiano, se tarde tanto en ser representado? Varias podrían ser las razones por las que

11 "En modo preliminar, es necesario poner la cuestión sobre la identidad o sobre la alteridad de estos temas iconográficos: de la cruz y de la crucifixión. Se trata de hecho de dos elementos que comúnmente son entendidos en modo evolutivo (de la cruz a la crucifixión), de la alusión críptica a la declaración explícita del sacrificio de Cristo. En verdad, los dos temas, prácticamente coincidentes sobre el plano de la compleja reflexión escriturística y patrística, sobre el plano iconográfico, precisa e indudablemente conectados, pertenecen a dos distintos ambientes semanticos, respectivamente simbólico y representativo" (Felle, 2000, p. 158).

12 En su Historia Eclesiástica, Eusebio de Cesarea (ca. 275-339) nunca se refiere a la inventio crucis, es Gelasio (¿?-496), su discípulo, quien narra en su Historia de la Iglesia -escrita hacia el 390- los detalles del descubrimiento; el texto quedó perdido, pero Rufino lo cita en su Historia Ecclesiastica (I, VIII. PL XXI, 476-477). Lo retomará posteriormente la Legenda Sanctorum - Leyenda Dorada- de Santiago de la Vorágine a mediados del siglo XIII con sus evidentes efectos en la iconografía del Renacimiento.

13 La stauroteca más famosa es la del Emperador Justino II y su esposa Sofía a la ciudad de Roma como reza en la inscripción que lleva, en el 578 (cf. Borgia, 1779, p. 14).

14 "El sentido simbólico de la crucifixión, no atenta contra el hecho histórico ni lo modifica, sino que lo explica adicionalmente" (Cirlot, 2008, p. 157).

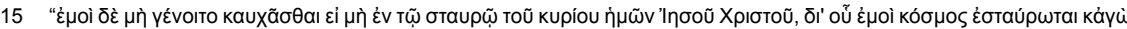
кó $\mu \omega$ ". En la Vulgata aparece: "Mihi autem absit gloriari, nisi in cruce Domini nostri lesu Christi, per quem mihi mundus crucifixus est, et ego mundo”. 
es posible comprender el inicial silencio y la posterior difusión con todas sus variantes en el arte de los orígenes del cristianismo.

Por una parte, el tema de la crucifixión habría traído a la memoria la terrible vergüenza del suplicio de la cruz, como nos lo han trasmitido las fuentes históricas ${ }^{16}$. Los crudos eventos de la ejecución de un condenado eran un espectáculo desagradable, que no tuvo nada de privado si bien hubo condenados a los que se ejecutaba en la más triste y dolorosa soledad. Extrañamente los Padres de la Iglesia hasta Agustín de Hipona (354-430) son unánimes en reconocer que la crucifixión de Cristo debió llevarse a cabo en completa desnudez (Craveri, 2005, p. 314); esta hipotética concordancia con las fuentes históricas que refieren tanto la crucifixión como el martirio de tantos cristianos por vía de la cruz, pero tampoco impulsará esta representación iconográfica.

Mientras que Cirilo de Jerusalén insistía en el orgullo del triunfo de la cruz en lugar de la vergüenza que suponía tal condena, Juan Crisóstomo (347-407) a finales del siglo IV propuso la imagen optimista del Rey en la cruz, no tan ajustada a la realidad, aunque fuese una verdad teológica: "porque lo veo crucificado por eso lo llamo rey: ya que es propio de un rey morir por sus súbditos"17.

No se puede esperar para entonces que la desnudez de Cristo en la cruz fuese un aspecto para destacar, si la escena de la crucifixión estaba ya en entredicho. El carácter simbólico de la cruz es el que triunfará sobre el lenguaje explícito o si se quiere realístico de cuanto leemos en los evangelios canónicos.

¿Se pensaría tal vez que el simple signo de la cruz explicaría completamente la totalidad del mensaje salvífico de la crucifixión que ella contenía? Posiblemente, las primeras comunidades cristianas encontraron más necesario y urgente el mensaje de la salvación, de victoria, de rescate, sin tener que pasar seguramente por el tema escandaloso de la crucifixión; máxime cuando para la cultura

16 Dionisio de Halicarnaso (primer siglo a. C.) describe esta antigua práctica: "los hombres quienes se les ordena llevar al esclavo a su castigo, habiendo extendido sus manos las atan a un pedazo de madera extendido por su pecho y hombros hasta sus muñecas, siguiéndolo, desgarrando su desnudo cuerpo por los latigazos" (Antigüedades Romanas, 7.69.1-2). Antes que la cruz tuviese el valor ulterior de instrumento de victoria: "signum salutis" y también de "signum Christi", es preciso considerar que con Constantino la cruz será considerada además signo imperial, pero no sin antes superar el terror que revestía semejante crueldad que, a los ojos de los mismo romanos, causaba terror y humillación: "crudelissimum teterrimum supplicium", dice Cicerón In verrem, 2, 5, 165. Y también: "supplicium servile", agrega Tacito Historiæ 2, 72. Cicerón Contra Verres V, 161 y 162: "aguardaban todos a dónde llegaría por fin o qué haría, cuando, de repente, manda que se aprese al hombre y que se le desnude y se le ate en medio del foro y que se saquen las varas [...]. Mientras imploraba con más insistencia [...] se le preparaba una cruz". Suetonio en su obra Nerón integrante de Los doce césares, sobre un tormento que sin ser una crucifixión, sí pertenece a la familia: "el criminal era desnudado, atado por el cuello a una estaca y entonces golpeado hasta la muerte con una cuerda" (op. cit. 49, 2). Séneca el Joven escribió: "veo cruces en ese lugar, no todas del mismo tipo, sino construidas de distintas maneras por unos y otros: hay quienes cuelgan a sus víctimas cabeza abajo, otros las empalan, otros extienden los brazos sobre el patíbulo...". "Diálogo de consolación a Marcia" 6.20.3. Eusebio de Cesarea, hablando de los mártires cristianos de Tebaida, relata la siguiente tortura en la que la desnudez representaba uno de los principales alicientes: "ataban a las mujeres por un pie y las suspendían en el aire mediante unas máquinas, con la cabeza para abajo y el cuerpo enteramente desnudo y al descubierto, ofreciendo a todos los mirones el espectáculo más vergonzoso, el más cruel e inhumano de todos" (HistEc. 8, 9, 1).

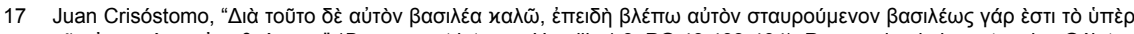

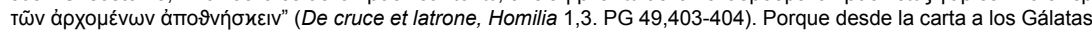
3:13: "Christus nos redemit de maledicto legis factus pro nobis maledictum, quia scriptum est: "Maledictus omnis, qui pendet in ligno"'“, Pablo supera la maldición del Deuteronomio 21:23: "quia maledictus a Deo est, qui pendet in ligno", terror que persistía incluso en ambientes paganos. 
grecorromana acostumbrada a las teofanías mitológicas y a las apoteosis de los dioses la idea de un hombre cubierto de oprobio, expuesto al suplicio más ignominioso y condenado a la pena más humillante, debió crear muchas dificultades cuando se hablaba de un Dios con semejante fin (Leclercq, 1907-1953, pp. 3.045-3.046). Ese temor se mantuvo. Se pensaba que ello minimizaba la condición mesiánica de Jesús que aceptó ese tipo de muerte en la cruz ${ }^{18}$.

Otro de los problemas es la comprensión del papel comunicador de la materia. En términos generales los Padres de la Iglesia prefirieron destacar el valor trascendente del arte, haciendo primar el carácter simbólico de la materia. Pero, mientras que algunos -como Tertuliano- la censuraban fuertemente "aunque sea de yeso, si tiene colores, si es de piedra, de bronce, de plata o incluso de hilo" (De Idolatria 3, PL I, 664-665), porque recordaba al ídolo, de otro lado -Clemente de Alejandría- con el cuidado de proteger a los cristianos de incurrir en la idolatría ofreció un reducido repertorio de imágenes compatibles, útiles y aptas para comunicar los misterios de la salvación:

Nuestros sellos sean una paloma, o un pez, o un navío a pleno viento, o la lira de la que se servía Polícrates, o el ancla de una nave que esculpió Seleuco hizo grabar; si está figurado en ellos un pescador, que nos recuerde a los Apóstoles y a los discípulos que son pescados en el agua (Pædagogi III, 11. PG VIII, 633).

Este tipo de sellos generalmente en forma de anillos adoptados a modo de emblemas familiares cuya impronta alcanzaba a tener valor jurídico en documentos públicos, se aprovecharon para difundir estratégicamente los signos más claves en los que se apoyaba la fe en Cristo. De no ser que se los considera de difícil datación e incluso de dudosa autenticidad ${ }^{19}$, los que nos han llegado hasta hoy, con el tema de la crucifixión, son una verdadera sorpresa por la audacia con que se representa al crucificado (figura 3) (cf. Spier, 2007, pp. 127-128).

En el muestrario que aconsejaba El Pedagogo de Clemente de Alejandría no estaba referenciada por parte alguna la representación de la crucifixión (Spier, 2007, p. 15), por lo que es poderosamente claro que nunca antes de los siglos V-VI ni en Roma ni en Siria se puede hablar de un testimonio iconográfico de la crucifixión y mucho menos de la explícita desnudez de Cristo en ella, como lo pretenden demostrar estas piezas ${ }^{20}$.

18 Como lo anuncia Pablo en Filipenses 2:8, indigna de un ciudadano romano y de un hombre libre el nombre mismo de la cruz debe estar alejado no solo de la persona de los ciudadanos romanos, sino también de sus pensamientos, sus ojos y sus oídos (cf. Cicerón, Pro Rabirio 5:16; Toscano, 1960, p. 79). 19 "No hay pruebas de su existencia, ya en el siglo III, de imágenes de crucifixiones en colecciones particulares o en
lugares de culto. Las primeras representaciones datan de siglo V y VI con algunas gemas talladas sobre su superficie pero de dudosa autenticidad y datación" (Sacco, 1997, p. 194; cf. Spier, 2007, p. 178).

$20 \mathrm{H}$. Leclercq no considera, por ejemplo, que el nimbo representado en las figuras 27 y 28 es un elemento iconográfico posterior al siglo IV, nunca antes de la paz constantiniana; en cambio, afirma deliberadamente: "ces monuments sont incontestablement antérieurs à la paix de l'Ėglise et nous offrent ainsi des types du crucifiement au Ile et au Ille siècle" (Leclercq, 1907-1953, p. 3.050). 
Los expertos ponen en entredicho una iconografía tan precoz, que va más allá del símbolo, como lo preveían los Padres.

Resulta del todo curioso aunque fuera natural que en estos dos casos lleven la inscripción griega que alude a un tal "EHCOX/PECT/OC", "I "Jesucristo". Pues, tanto en el caso del jaspe rojo de Gaza en Siria (figura 4), con una figura femenina (a la derecha) y una masculina (a la izquierda), como la pieza descubierta por el p. Garrucci (figura 5) en el que la figura humana está flanqueada por doce personajes. Todavía es más curioso que en estas representaciones se insinúe la figura desnuda.

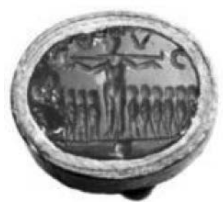

Figura 3. Cornalina, Catálogo “Dalton” pl. 1, n 43.

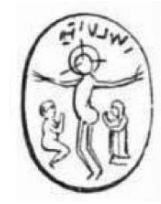

Figura 4. Jaspe rojo, Boletín de la Sociedad de Antigüedades de Francia 1868, p. 111.

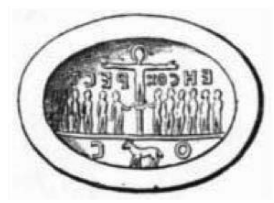

Figura 5. Cornalina, Guarrucci, Storia, pl. 479, $\mathrm{n}^{\circ} 15$.

\section{El crucificado del Palatino}

Los estudiosos han querido explicar muy extendidamente la intencionalidad original del notable grafiti blasfemo de Alexamenos que surge entre los siglos II-III en el Prdagogium del Palatino (figura 6) ${ }^{21}$. Se dice que representa con

21 "Parece extraño que el crucificado esté revestido de una túnica (colobium), porque las imágenes más antiguas lo representan desnudo, con la sola faja entorno a las piernas (subligaculum)" (Sacco, 1997, p. 194). 
particular carácter panfletario una mofa contra los cristianos como adoradores de un dios-asno; de ello no hay duda ${ }^{22}$.

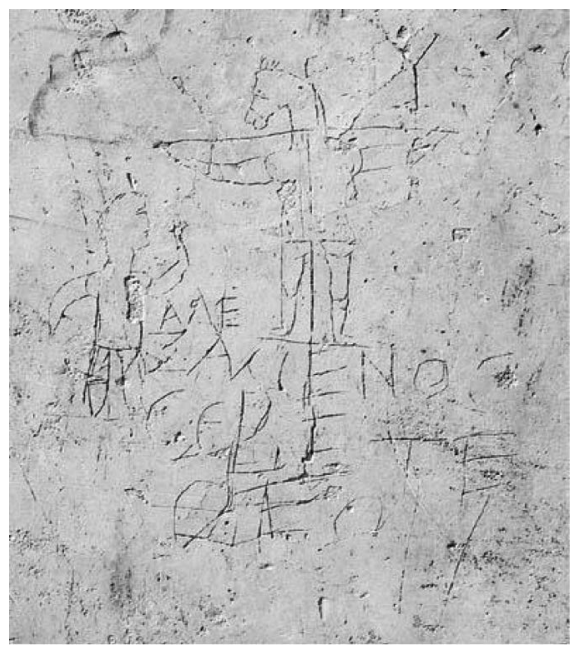

Figura 6. Pædagogium Palatino. Grafito de "Alexamenos adora a su Dios", Roma, siglo II ca.

El grafiti no nace en el seno de la comunidad eclesial ni como imagen de culto o con una intención votiva. No se trata de una imagen cuyo fin sea la devoción, más bien se trata de una representación razonada y calculada para injuriar y no solamente al Dios de los cristianos que tiene cabeza de asno ${ }^{23}$. Dejando de lado la gestualidad de Alexamenos como el hecho de lanzar besos con la mano izquierda ${ }^{24}$ el acento insultante de la representación de este crucificado no estaría directamente en el sentido mordaz de la personificación de un dios-asno, cosa que en realidad poco o en nada ofendería a los cristianos como lo refuta Tertuliano: "algunos han soñado que nuestro Dios tenga cabeza de jumento" (Apologeticus XVI, 1-3 PL I, 364) ${ }^{25}$. El énfasis de la burla podría estar en la postura

Único entre más de trescientos, fechados entre el siglo II-III, representa a un crucificado con cabeza de asno, cortejado a su

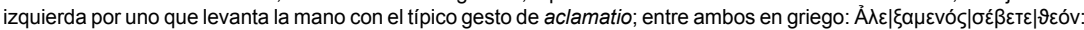
"Alexamenos adora a [su] Dios" (Carletti, 2008, p. 140; cf. Sacco, 1997, pp. 193-194; Réau, 2000, p. 495; Leclercq, 1907-1953, pp. 3.051-3.052).

Cecilio, hombre pagano, dice a Octavio: "audio eos [cristianos] turpissimae pecudis caput asini consecratum inepta nescio qua persuasione venerari” (Marci Minucii Felicis, Octavius IX. PL I, 261).

24 El gesto de iactare basia, nada tiene de la pietas pagana: plegaria hecha con ambos brazos extendidos en alto (cf. Carletti, 2010). La burla en cambio la mencionan los sinópticos, mientras Jesús pende la cruz: "alios salvos fecit; se salvum faciat" (Mt. 27:39; Mc. 15:29; Lc. 23:35).

25 La burla a los cristianos injuriaría a judíos, quienes en Egipto, estériles de agua, fueron afligidos por la sed, pero viendo salir jumentos silvestres del pasto les siguieron, y por sus huellas hallaron venas de agua; ellos, agradecidos con el animal que los guió, tuvieron en mucho respeto la bestia. Y como los cristianos convienen en algo con los judíos, interpretaron los malévolos que también ellos adoran la cabeza de este animal (cf. Tertuliano, Ad Nationes I, 11; 14 PL I, 577; 579). 
de espaldas que evidencia las caderas del crucificado. Indirecta pero probable alusión a las condiciones en que morían así los condenados ${ }^{26}$.

Observando detenidamente el grafiti, se nota muy bien el palo vertical de la cruz que la anatomía del crucificado no oculta. Atraviesa toda la contextura del tórax y se aprecian muy claramente dibujadas sus caderas. Incluso el pliegue dibujado en lugar de la rótula que anuda las rodillas sugeriría la posición de espaldas del condenado ${ }^{27}$. El crucificado, habría sido representado de espaldas con un ingrediente más de mofa, pues ya el panfleto quiere desprestigiar al Dios muerto de los cristianos tomando por ilusos a sus seguidores cuando pretenden seguir sus ingenuas enseñanzas.

La hipótesis de un asno desnudo y crucificado, sigue admitiendo todo tipo de lecturas e interpretaciones. Pero desde que fue hallado en 1856 por Raphael Garrucci, se dice que el condenado no está del todo desnudo. Viste en cambio un colobio bastante corto que expone sus glúteos, cosa que infringiría mayor vergüenza si bien no expone una completa desnudez en este caso.

Evidentemente la burla no solo busca desprestigiar la religión y la fe judeocristiana, sino que pretendía además restarle importancia a la fe cristiana cada vez más creciente desfigurando la condición humana de Jesús. Pero la fealdad de este Jesús ya la habían planteado los Padres de la Iglesia. La desfiguración de la condición carnal del Mesías en su injusta Pasión y muerte era una idea bastante tratada en los primeros siglos, cuando se piensa que la imagen del Siervo doliente de Yavé, profetizada por Isaías 53:2: "no había en él belleza alguna" se refiere concretamente a Jesús de Nazaret ${ }^{28}$.

\section{Lconografía que nace entre disputas teológicas}

El cristianismo de la paz constantiniana, supuso un considerable apoyo de la nobleza imperial a las comunidades como a sus dirigentes: Papas, obispos y presbíteros supieron usar de una generosa cantidad de ayudas materiales así como de todas las facilidades y recursos necesarios -arquitectos por demás-con los que antes no se contaba.

26 "La figura humana no está desnuda así como estaba todo crucifijo ante los ojos de todos sino vestida de una especie de camicia, llamada interula y de una tuniquita suelta a la cintura y puesta encima; las tibias quedaban cortadas por aquellas fajas, que por ello eran llamadas crurales ["piernales"]. Al lado izquierda de quien mira hay una figura humana que parece estar en coloquio con la monstruosa imagen crucificada elevando la izquierda y con los dedos de la mano extendidos, también ella tiene la misma tuniquita" (Garrucci, 1856, pp. 530; 529-547).

27 "Allí está representado -visto por detrás- un hombre con cabeza de burro colgado a una cruz commisa (en forma de $\mathrm{T}$ ), vestido de una túnica adherida (interula) y de una tuniquita suelta sin mangas, era el famoso colobium, indumento típico de esclavos" (Carletti, 2010).

Comentando el texto de Isaías los Padres de la Iglesia unánimemente coinciden en la idea de la fealdad del Mesías; el primer referente lo encontramos en Justino (Dialogus cum Tryphone ludeo, 85, 88, 100; PG VI, 676, 686, 710); luego en Clemente de Alejandría (Pædagogi III, 1; PG VIII, 555; cf. Stromata, VI, 17; PG VIII, 382); así como en Orígenes (Contra Celsum, VI, 77; PG XI, 1414) y en Tertuliano (Adversus Iudæos 14, PL II, 638-639; cf. De carne Christi, IX, 4-8. PL II, 770-773) (cf. Zorzi, 2007a, pp. 269-292). 
Con este potencial se irán estableciendo y con progresiva propiedad aquellos primeros modelos iconográficos que configurarán, por muchos siglos, todo el lenguaje de la plástica cristiana. Pero con la misma celeridad con que surgen los referentes iconográficos la teología tendrá que jugar el papel de árbitro sobre ellos.

El silencio o al menos la ausencia de significativas representaciones artísticas de la crucifixión en los primeros siglos del cristianismo, se interrumpe con dos particulares que nos han llegado hasta ahora de un considerable valor plástico y no menos teológico, como es típico del primer arte cristiano.

El primero de ellos, se destaca por la importancia y la categoría del recinto que lo alberga: la basílica de Santa Sabina sobre el monte Aventino en el corazón de la capital del Imperio: Roma (figura 7). El segundo es un relieve de marfil, presumiblemente elaborado en Roma -ahora en el Museo Británico- y que los estudiosos han fechado unánimemente entre los años 420-430 d. C. (Figura 8).

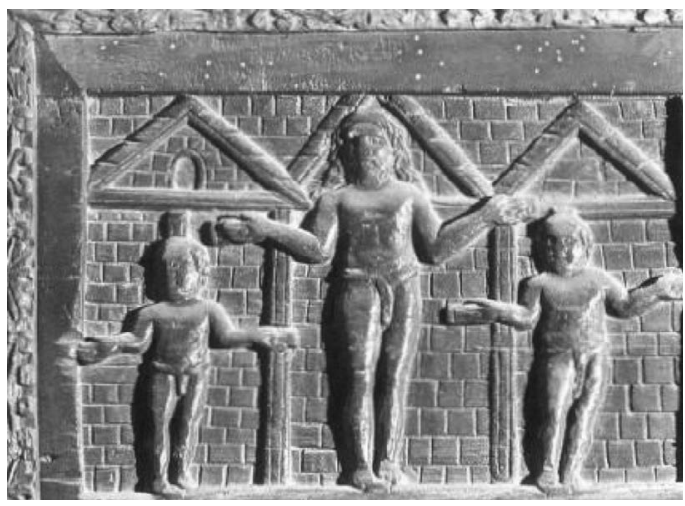

Figura 7. Basílica de santa Sabina. Crucifixión, detalle de la puerta principal en madera del siglo V.

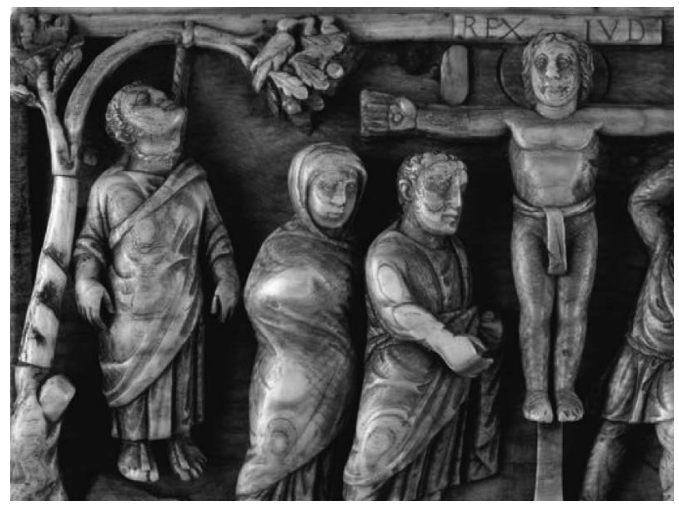

Figura 8. Cristo crucificado. Marfil del museo Británico. S. IV d. C. 
En el particular de la puerta de madera de Santa Sabina, cuya decoración probablemente se llevaría a cabo, si no por orden, al menos según el querer del papa Celestino I (422-432) ${ }^{29}$, encontramos una muralla como telón de fondo de un patíbulo de tres condenados a muerte en la crucifixión.

Es la representación de las afueras de Jerusalén, donde según las fuentes bíblicas fueron ejecutados estos tres hombres. Sin más elementos iconográficos, cabe precisar que se destaca solo el crucificado del centro de la escena, por la proporción y el tamaño que ocupa, con respecto a los dos condenados.

Se lo ha representado en actitud de orante, expansis manibus ${ }^{30}$ y clavado aunque ocultando el leño horizontal de la cruz. Sus pies no están clavados, se apoyan en el suelo, como no ocurre con la pieza de marfil del Museo Británico. En este, un tanto más narrativo, contrastan las figuras de Judas y Jesús en un impresionante, irónico y dramático combate entre muerte y vida ${ }^{31}$.

Estas primerísimas imágenes del Crucificado, en realidad semidesnudo, representan al condenado con dos variantes. Con la barba y de cabellos largos en la placa de madera, modelo que la posteriodad conocerá como el sabiniano contrario al imberbe y apolíneo, siempre atlético, del modelo de marfil del Museo Británico.

Lo característico en ambos casos es que el condenado viste únicamente el famoso subligaculum ${ }^{32}$ que generalmente era una prenda de lino, cruda, burda y sin adornos, muy común entre esclavos hindúes, nada ajena a la cultura romana amante de las termas públicas, pero mucho más frecuente entre los griegos, tan dados a las prácticas deportivas y a las actividades lúdicas en completa y libre desnudez.

Ambos referentes, en la más temprana representación iconográfica de la crucifixión, se sirvieron de un lenguaje prestado de los espectáculos públicos. Cristo

29 En su pontificado debió hacer frente a algunas doctrinas heréticas que culminaron con la celebración del Concilio de Éfeso y, que en el 431 supuso la condena de algunas de ellas como el nestorianismo, que separaba las dos naturalezas de Cristo y definía a María como la Xрıбтото́ (madre de Cristo), generadora carnal de Jesús, pero no como

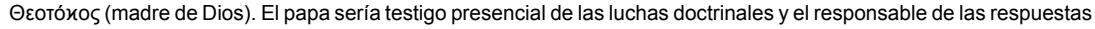
teológicas, sin excluir las artísticas.

30 Raro en el crucificado pero totalmente lógico y típico como tantas representaciones de mártires en el clásico gesto de la pietas romana (cf. Bisconti, 2009).

31 El suicidio de Judas cuyo cuerpo rígido pero vestido al uso romano, contrasta con el de Jesús semidesnudo en la cruz. Con respecto al de la Basílica de Santa Sabina, la atmósfera es más sangrienta y terrible aunque paradójicamente allí tiene un aspecto más sereno y triunfal el Cristo, aunque desnudo (cf. Gough, 1973, p. 130).

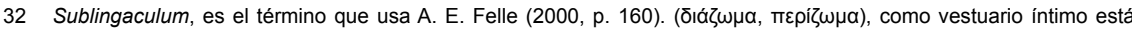
ampliamente documentado en historiografía antigua, Flavio Josefo: Ant. III.7 § 1; Clemente Alejandino: Paedag. III.9; Virgilio. Aen. XII.120. La braga, en italiano; braie, en francés, prenda no exclusivamente femenina, ya era usada pueblos asiáticos incluso bárbaros; de uso muy común entre los pueblos pesqueros emplazados en las riberas de los ríos o en las costas de los mares (cf. Leloir, 1951, pp. 43-44). 
entonces, venía asimilado al atleta griego victorioso ${ }^{33}$, era el gladiador romano vencedor; figura iconográfica que no se volverá a ver en adelante ${ }^{34}$.

Esta clase de mensaje expresado en el Cristo-gladiador y en la figura del Cristoatleta, fue codificado temporalmente por el arte paleocristiano que caducará bien pronto; la prueba es que se conocen solo estos dos ejemplos. Vendrá la reforma carolingia, cuando en el Medioevo se representará al Crucificado con el clásico perizoma. Nunca más con el subligaculum.

En este mismo contexto, el surgimiento del Docetismo, de la mano del Monofisismo $^{35}$ habrían afectado teológicamente la manera de entender y proclamar la fe en la persona de Cristo: especialmente en el dogma de la conjunción unitiva de sus dos naturalezas: divina y humana, sin división ni preeminencia de alguna de ellas.

Durante los convulsionados siglos IV-V delicadas cuestiones sacudían a la Iglesia, que de otro lado veía cómo crecía y abundaba el lenguaje plástico del que se servía para hacer más eficaz el mensaje del Evangelio. El Concilio de Calcedonia profesará con meridiana claridad que "en Cristo existe una sola persona con dos naturalezas" ${ }^{36}$. Sin embargo la tensión teológica continuará extendiéndose por casi tres siglos ${ }^{37}$. Eso hará posible -pese a la fugacidad del modelo sabiniano- la maduración de la reflexión teológica, la construcción del dogma de la persona de Cristo y todo lo concerniente a su corporalidad.

El arte no siempre pudo secundar lo que la teología enseñaba (Toscano, 1960, p. 86). Por eso, cuando desaparece el modelo sabiniano, desaparece también el cuerpo de Cristo. Eso se nota de dos formas: en primer momento, reaparece la

33 La figura del Athleta Christi: luchador-competidor no es ajena al imaginario bíblico (1 Mac. 1:14; 2 Mac. 14:12; 1 Cor. 4:9; 9:24-27; Fil. 2:16; Col. 1:29; 1 Tim. 6:12; 2 Tim. 2:5; 4:6-8; Hb. 10:32-34; 12:1) y es sinónimo del esfuerzo heroico, de la superación de sí mismo, de las limitaciones psico-físicas y el ideal de la auténtica vida cristiana que no excluye la idea del martirio como consecuencia del simple esfuerzo personal o del extremo sometimiento a la prueba (cf. Giuliani, 2000, pp. 131-132). Pese a la censura ya manifiesta en la literatura patrística de tales espectáculos públicos, san Agustín los sustituye por los spectacula christiana aunque las basílicas sepulcrales a forma de circo (circiformes) ya reflejaban dicha metáfora (cf. Heid, 2006, p. 645).

34 Este tipo, [con el perizoma] perdurará todavía en las miniaturas carolingias en donde la desnudez del Cristo solo estará velada por un ceñidor (Réau, 2000, p. 496).

35 El Docetismo a finales del siglo I d. C., afirmaba que Cristo no sufrió la crucifixión porque su cuerpo solo era aparente, no real. De influencia platónica, piensa que las ideas son las únicas realidades y nuestro mundo es solo un reflejo, una imagen; además, se nutre de la idea por la que la materia, hace del cuerpo una cárcel del espíritu, propio del dualismo griego. Enraizado también en el dualismo gnóstico, dividía tajantemente los conceptos de cuerpo y espíritu, atribuyendo todo lo temporal, ilusorio y corrupto al primero y todo lo eterno, real y perfecto al segundo; de ahí que el cuerpo de Cristo fuera solo una ilusión y que, por tanto, su crucifixión mera apariencia. Por su parte el Monofisismo, sostenía que en Jesús estaría presente la naturaleza divina, no la humana. Sostenía, además, que en Cristo existen las dos naturalezas, "inseparables" pero "confundidas", de forma que la naturaleza humana se pierde, absorbida, en la divina (Jedin, 1970, p. 236; cf. Danielou y Marrou, 1982, pp. 384-402).

36 El canon 301, sanciona: "siguiendo por tanto a los santos Padres, con unanimidad enseñamos a confesar un solo e idéntico Hijo: el Señor nuestro Jesucristo, perfecto en su divinidad y perfecto en su humanidad, verdadero Dios y verdadero hombre [compuesto] de alma racional y de cuerpo, consustancial al Padre por la divinidad y consustancial a nosotros por la humanidad, semejante en todo a nosotros fuera del pecado" (cf. DZ, p. 168).

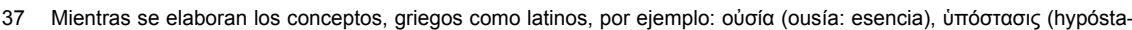

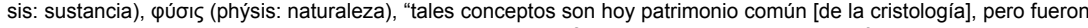
entonces acuñados o debieron recibir un nuevo contenido. El fruto más prominente de esta reflexión es el concepto de про́бштоv (prósopon: persona)" (Schönborn, 1999, pp. 27- 29). 
crux gemmata, la crux invicta, símbolo del triunfo de Cristo sobre la muerte ${ }^{38}$. En un segundo momento la estética cristiana recurre al bestiario para representar a Cristo con un cordero (figura 9); esquema iconográfico que censuró en el año 692 el III Concilio de Constantinopla, llamado Trullo o Quinisexto. Con el canon 82 , se cancelaban este tipo de representaciones y se recomendaba a los artistas que se representara de nuevo "en su forma humana" (Belting, 2009, p. 210; cf. Réau, 2000, p. 496).

El tema de la corporalidad de Cristo, en medio de las discusiones teológicas como las planteadas por Eusebio de Cesarea ${ }^{39}$ hará necesario todavía en los primeros

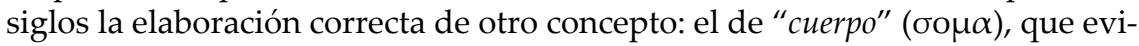
dentemente tendrá repercusiones importantes para la plástica ${ }^{40}$.

Ya este síntoma se empezaba a sentir en la representación de un Cristo sin cuerpo, únicamente el rostro -su rostro- y a veces sin la cruz, como puede notarse en tantos ejemplos, pero especialmente entre las famosas aceiteras de Tierra Santa, ahora en el tesoro de Monza (figura 10).

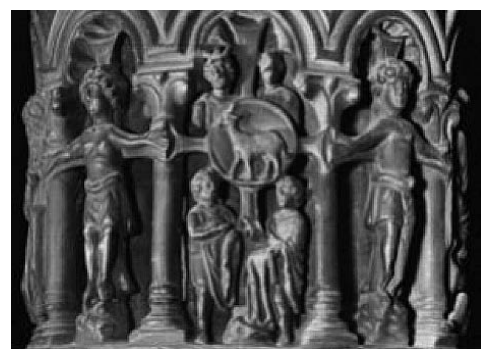

Figura 9. Relieve de alabastro. Jesús como cordero místico. Detalle de la columna del Ciborio de origen Sirio.

38 Basta considerar los mosaicos que decoraron las primeras basílicas cristianas a partir del siglo IV: Santa Pudenciana, la absidiola del siglo VII en la capilla de los mártires Primo y Feliciano de Santo Stefano Rotondo, en Roma; en Rávena: san Apolinar en Classe, san Vital, la capilla episcopal, el mausoleo de Gala Placidia, los más conocidos.

39 "Su doctrina cristológica de las dos naturalezas estaba toda centrada en la cuestión sobre la imagen; por ejemplo, describe a Cristo en la relación con Dios como "del todo incorpóreo", como "una férrea imagen viviente del Dios viviente", y por tanto totalmente diversa de las "imágenes terrenas", a las que falta siempre la sustancia de aquello que representan. Mas Cristo poseía al mismo tiempo un verdadero cuerpo por cuenta del cual se diferenciaba de las "imágenes de ídolos sin alma" como eran las paganas. Dicho cuerpo era "una pura imagen" y un "habitáculo de Dios sensiblemente percibible", y en esta corporeidad era superior a todas las statuas de los ídolos" (Belting, 2007, pp. 60-61).

40 "La pregunta sobre la presencia de Cristo implicaba también las imágenes físicas que se divulgaron por así decir como conceptos visuales del tema [...]. Los artistas, de otro canto, debieron dejar evidencia teológica legitimando las propias obras con los textos, con evidente alusión a lo que se referían. Se encontraron pues con el arduo trabajo de los demás artistas, nada menos, aparecía indudablemente tal. La imagene del cuerpo entró en el vórtice del discurso teológico, al cual no se le hizo enteramente justicia. El concepto occidental de cuerpo se equiparó a un modelo inigualable" (Belting, 2007, p. 106). 


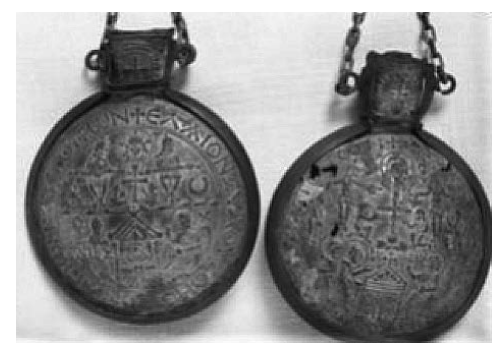

Figura 10. Aceiteras de Tierra Santa: $n^{\circ} 5$ y 11 respectivamente, Ampola del Peregrino. Museo del Duomo de Monza, Italia.

El problema será el mismo que planteaba Eusebio de Cesarea a la emperatriz Constanza: ¿qué cuerpo de Cristo pretendía ver ella en la imagen que tanto deseaba ella, el verdadero e inmutable (charaktéras: $\chi \alpha \varrho \alpha \varkappa \tau \eta \tilde{\varrho} \alpha \varsigma)$, o el que

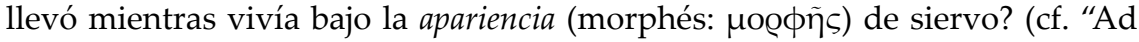
Constantiam Augustam" PG XX, 1545). La respuesta no será automática naturalmente. Se gestará con el tiempo la unificación de la dicotomía cuerpo-alma, sumado a la reflexión sobre la fealdad de Cristo (recordar nota 256), que buscaba conciliar la "de-formitas como dei-formitas" atribuyeron los artistas, así como los Padres de la Iglesia del Verbo encarnado. San Agustín, por ejemplo dice:

Bello es Dios, el Verbo ante el Dios; bello en el seno de la Virgen, bello el Verbo recién nacido. Bello también en el cielo, bello en la tierra, bello en las manos de sus padres; bello en los milagros, bello flagelado; bello invitando a la vida, bello cuando no se cuida de la muerte; bello entregando su alma, bello recibiéndola; bello en la cruz, bello en el sepulcro, bello en el cielo ${ }^{42}$.

\section{El triunfo del Colobio}

Sobre los modelos sabiniano-helenístico, compuesto por el particular de Santa Sabina y, mutatis mutandis, el del Museo Británico, que ya explicamos, triunfará ulteriormente el modelo sirio de la crucifixión. El más antiguo ejemplo se encuentra en la conocida página del evangelio "de los Rábbulos" ${ }^{43}$, compilado hacia el año 586 (figura 11).

41 "Para la condición divina de Cristo esto ha implicado, como dice la carta a los Filipenses 2:6-11 una "kénosis", una inaudita reducción. De aquí tomará cuerpo, en campo latino, la idea de una "de-fórmitas" como "dei-fórmitas". Una relación estrecha entre cuerpo e idea, materia y sentido, también lo feo tiene un propio sentido" (Zorzi, 2007b). cœlo, pulcher in terra, pulcher in manibus parentum; pulcher in miraculis, pulcher in flagellis; pulcher invitans ad vitam, pulcher non curans mortem; pulcher deponens animam, pulcher recipiens; pulcher in ligno, pulcher in sepulcro, pulcher in cœlo" (Agustín, Enarratio in Psalmum 44, 3. PL. XXXVI, 495). 
Este modelo alcanzará a inspirar casi de manera sistemática el tema de la crucifixión que perdurará hasta el Medioevo, con una fuerza mayor que la del modelo anterior. Basta recordar la famosa cruz pectoral, con este mismo esquema iconográfico que Gregorio Magno donó a la emperatriz longobarda Teodolinda hacia el año $603^{44}$ (figura 12); la decoración de una sección de la catacumba de Valentín sobre la vía Flaminia en el siglo VIII bajo el pontificado del papa Juan VII (705-707; figura 13), el Crucificado de Santa María Antigua, elaborado durante el pontificado del papa Zacarías (741-752; figura 14) y en el oratorio de Santísimo Salvador en la domus ecclesiæ de los santos Juan y Pablo, fechado a fines del siglo VIII ${ }^{45}$.

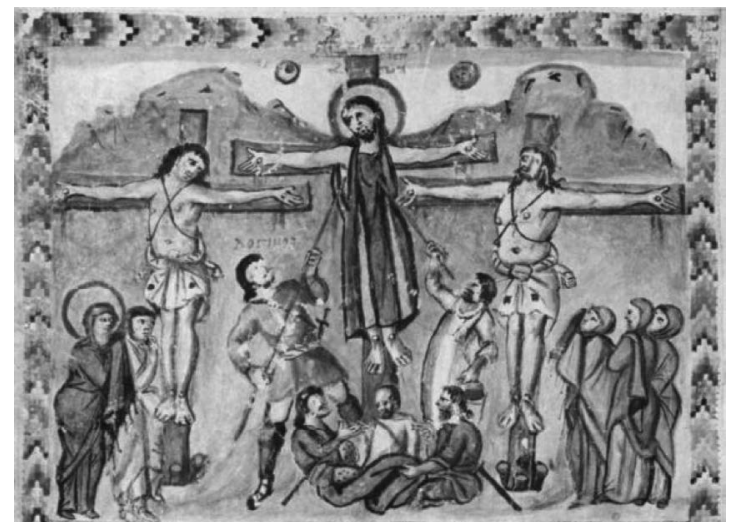

Figura 11. Evangeliario de Rabbula. La Crucifixión. Biblioteca laurenciana de Florencia, Italia. 586 ca.

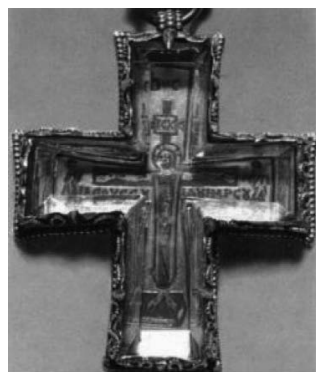

Figura 12. Cruz pectoral de Gregorio Magno dada en dono a Teodolinda en el 603, también llamada de Adaloaldo.

al gusto occidental de representar el crucificado desnudo o al menos vestido del subligaculum como no aparece en el evangeliario de la Biblioteca Laurenciana de Florencia (cf. Thoby, 1959, pp. 24-25).

El dono se efectuó con ocasión del bautismo de su hijo Adaloaldo (cf. Conti, 1990, pp. 137-139).

"Quod ipse beatissimus papa magne constructionis fabricis atque picturis decoravit ; ampliavitque in eo fines ex omnia parte" (Duchesne, 1955, p. 434). 


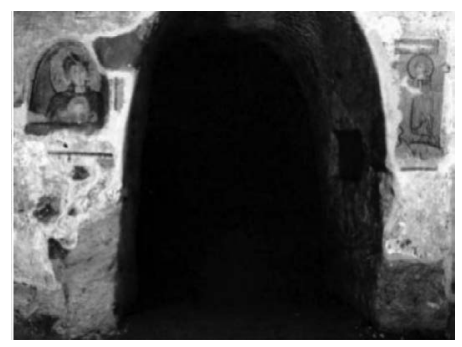

Figura 13. Catacumba de san Valentino, en el extremo derecho un particular de la Crucifixión en que viste Cristo el colobium.

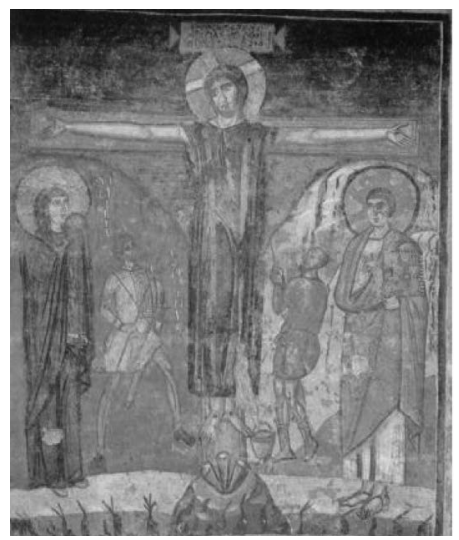

Figura 14. Santa Maria Antiqua. Crucifijo con María y Juan.

Roma, sobre el Palatino s. VIII.

En todos ellos Cristo viste el tradicional colobio de púrpura imperial (Toscano, 1960, pp. 100-101), compuesto esencialmente por una túnica de clavus, eran las fajas de oro sobre un atuendo color púrpura que era de uso exclusivamente imperial. La vestidura blanca distintiva de la clase política, de color crudo, solía llevar las clavia (cf. Gardin, 1825, p. 554) de color púrpura y de un ancho que variaba de acuerdo la dignidad senatorial. La clavata, era una túnica sin mangas o de mangas muy cortas, de uso más propio en la antigüedad romana que en principio no veía tan masculina la costumbre de vestir túnicas de mangas largas (Yates, 1875, pp. 1.173-1.174) ${ }^{46}$.

Fue mucho más tarde que al colobio se lo llamó levitón o levitonio ${ }^{47}$, adquiriendo con ello un sentido marcadamente litúrgico-sacerdotal, lo que generará a

Chiton en francés o khiton, kittama en arameo, kouttina en sirio, kouttônet en hebreo, es la misma túnica esencial de lino que hombres y mujeres desde época homérica vestían; constituida generalmente por dos piezas de tela muy ligeras iban cosidas en los hombros y en la cintura pélvica, lo que generalmente dejaba al descubierto los hombros, los brazos, las espaldas y las piernas (cf. Leloir, 1951, pp. 87-88). especialmente en Egipto, en donde se recuperó este gusto romano de vestir (Bastús, 1862, p. 321). 
posteriori un significativo cambio en la variante iconográfica de la maiestas ${ }^{48}$, el tipo de crucifixión que prevalecerá desde la tardo- antigüedad cristiana hasta el Medioevo, como dijimos antes Italia, fue el centro de mayor difusión de este modelo iconográfico que se originó en Lucca $^{49}$. Un poco más tarde pasó a Cataluña ${ }^{50}$, difundiéndose ampliamente hasta llegar a Alemania ${ }^{51}$.

Este Crucificado como antítesis del completamente desnudo, no pretendía representar al Hijo del Hombre en el acto sacrificial de la cruz, sino al monarca de la gloria que ha escogido la cruz para trono y pedestal (Pijoán, 1966, p. 504).

Con el correr del tiempo, este tipo iconográfico vestido de la púrpura o de cualquier ropaje -como se nota en la figura 15- sobrepone la dignidad mesiánica del Cristo a su condición humana. Se subraya la condición soberana, sobre todo la función sacerdotal de su muerte en cruz; lo que convierte de plano a este tema, en otro discurso que aquí no tiene sentido sondear ni pormenorizar.

El par de modelos que se ajustan al esquema sabiniano, son los únicos ejemplos que pueden confrontarse con el modelo sirio vestido de colobium, de túnica clavata. Ambos esquemas conviven y definen la iconografía de la crucifixión de Cristo al menos hasta la reforma carolingia. Por falta de otros ejemplos no es posible hacer otro tipo de confrontación. Sabemos que el modelo sirio, nació en el seno de comunidades monásticas de origen oriental, que se empezaban a establecer permanentemente en Roma, como una suerte de cristianismo triunfante.

La idea de fondo que el cristianismo victorioso del siglo IV-V haya encontrado incompatible con su mensaje un arte corpóreo de la era clásica es exacta, como exacta es la afirmación que -por "erradicar" y "extirpar" el error- la Iglesia ha dado la espalda a los ídolos, y, con el edicto de Teodosio del 391 ha cerrado los templos paganos (Verdon, 2009, p. 53).

48 El término deriva, además de la vestidura larga y majestuosa, también por "la alta corona postiza de metal que las hace más imponentes. Aún sin corona, bastaría su gesto estrictamente frontal y sus ojos abiertos, sin señales de piedad, para imponer respeto, casi terror" (Pijoán, 1966, p, 504).

49 Si bien este tipo iconográfico está inicialmente documentado solo hacia el siglo XI, el actual Volto Santo de la Basílica Catedral de Lucca aparece a comienzos del siglo XIII (ca. 1200) como obra escultura perteneciente al círculo de Benedetto Antelami, a quien se atribuye también el grupo marmóreo de la famosa crucifixión que está en la Basílica Catedral de Parma (cf. Jászai, 1991- 2002, p. 584). Este tipo iconográfico con barba larga y perizoma a modo de faldas se popularizará en occidente a causa de la Santa Faz (volto santo) de dicha ciudad (cf. Réau, 2000, p. 496).

50 Se cree que esta iconografía, de cuyo más claro exponente son la de Baget en Gerona, de casi tres metros de altura y la llamada Majestad Batlló. Hay quien sostiene que la santa imagen de Lucca sería en verdad de origen catalán pero es más sensato pensar que fue llevada a Cataluña, por los pisanos, cuando llegaron en 1114 para ayudar al conde de Barcelona Ramón Berenguer III en su conquista de las Baleares (cf. Pijoán, 1966, p. 505).

51 Entre algunos ejemplos, podríamos proponer el famoso crucifijo de Imerward, de la Catedral de Braunschweig, datado en el siglo XII, igualmente proveniente de la tradición italiana y catalana (cf Viladesau, 2006, p. 66). 


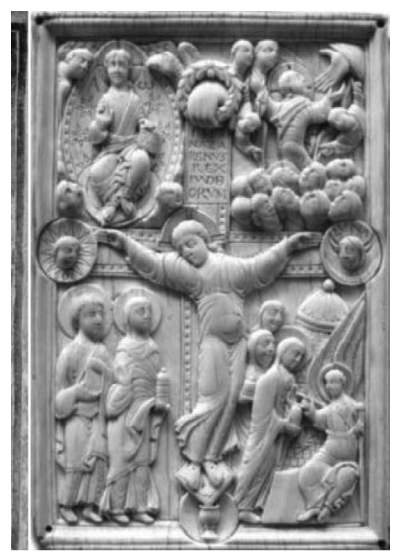

Figura 15. Marfil anónimo de la Renania, finales del s. X-XI.

Museo medieval de Cluny, París, Francia.

Tal vez este factor propaga este tipo de imágenes con mayor fuerza, definiendo el triunfo del modelo sirio sobre el sabiniano, lo secular contra lo sacro. Pero ello no se debe únicamente a la introducción de una variante más con la vestidura talar; sucede que el Cristo atleta-gladiador empieza entonces a perder vigencia ${ }^{52}$. Las fervientes comunidades monásticas, entre los siglos $\mathrm{V}$ al VII difunden una iconografía litúrgico-devocional, haciendo primar algo más que el gusto ${ }^{53}$.

Al margen de los factores devocionales, de gusto o de aceptación de cualquiera de los dos modelos, hay otro elemento que evidencia A. M. Romanini cuando explica que el conflicto lo determinaba la comprensión de la figura humana de Jesús en la cruz. El asunto fue tan difícil de asimilar para el pueblo como para el orfebre el hecho de elaborar un pectoral como el del papa Gregorio Magno ${ }^{54}$ (recuérdese la figura 12).

\section{La censura de Gregorio de Tours}

No parece haber sido el obispo de Hipona quien estableciera el fin de la tradición por la que algunos Padres de la Iglesia consideraban con certeza que Cristo

52 Entre la placa de madera de Santa Sabina y del marfil del Museo Británico podría haber una nueva diferencia más fuerte: no es igual que un cofre de marfil lo haya comisionado un particular porque -en cambio- a la puerta de Santa Sabina, sabemos la comisionaron eclesiásticos por encargo del papa Celestino I, (recuérdese la nota 32).

53 Es casi incontable la profusa difusión del crucificado vestido de colobio; lo indica la cantidad de cruces pectorales que se conocen hasta el siglo IX; se entiende así cuánto repugnaba la idea de presentar a los fieles al Redentor desnudo sobre la cruz (cf. Thoby, 1963, p. 10).

54 "Resolver tal contraste en una única imagen debió exigirle a los orfebres de tales cruces longobardas un esfuerzo al menos igual al trabajo de asimiliación de la figura humana" (cf. Romanini, 2007, p. 181). 
murió desnudo en la cruz. Las noticias que ofrecen al respecto los evangelios canónicos $^{55}$ son escasamente esenciales ${ }^{56}$.

Contrasta con esto el testimonio de Melitón de Sardes (ca. 138-ca. 190) quien afirma que el Mesías "estaba desnudo sobre el madero" ${ }^{57}$. Concuerdan en esta idea Ambrosio de Milán (ca. 340-397), en Juan de Jerusalén (356-417), en Juan Crisóstomo y en Proclo, obispo de Constantinopla (412-485) ${ }^{58}$. Naturalmente la idea de desnudez en estos autores no es siempre la misma ${ }^{59}$. Llevar el pecho descubierto, llevar puesta solo la prenda íntima -como el subligaculum-que cubría los genitales era considerada igualmente una desnudez, parcial en todo caso.

La primera vez que se tiene noticia del perizoma ${ }^{60}$, es en la literatura al margen del Nuevo Testamento, se trata del evangelio apócrifo de Nicodemo o Acta Pilati $^{61}$. Justamente este es el contexto en el que podemos situar la intervención de Gregorio de Tours ${ }^{62}$ en lo que se refiere a la representación del crucificado desnudo durante este espacio de tiempo (ca. 538-594).

Ya en su Historia Francorum, Gregorio de Tours habría insinuado que una dama -de su propio peculio- habría hecho construir y decorar una iglesia dedicada a San Esteban. Se dice que mientras ella leía un libro que no se precisa, le indicaba y advertía a los artistas la manera concreta y específica de representar los temas iconográficos ${ }^{63}$. Desde luego que el tema al que se refiere expresamente

55 Mt. 27:35; Mc. 15:24; Lc. 23:34 y los detalles en lo 19:23-24, únicamente.

56 Contrasta la más retórica en Jn. 3:16, con la más explícita en Flp. 2:8.

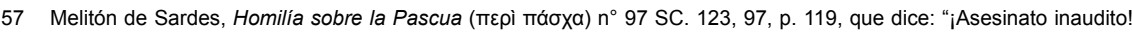

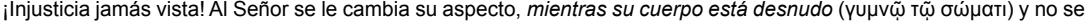
le juzga digno de un vestido por pudor. Por eso se dieron vuelta las luminarias, y así se oscureció el día, para ocultar

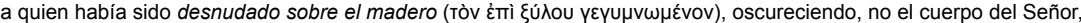
sino los ojos de los hombres" (cf. Ibáñez y Mendoza, 1975, pp. 208-209; Cantalamessa, 1972, p 48).

58 Ambrosio, "interesa considerar cual sube a la cruz, desnudo le veo" $P L 15,1353$. El sucesor de Cirilo de Jerusalén, declara: "os habéis desnudado de vuestra túnica [...]. Estabais desnudos, imitando también en esto al Cristo desnudo en la cruz [...]. Estabais desnudos a la vista de todos y no sentíais vergüenza" Juan de Jerusalén, Catech. Myst. 3,2. "Aquí en el calvario desnudez, y allí en el paraíso desnudez" Juan Crisóstomo, Catech. 3,8. Proclo de Constantinopla, In ST 247, 193. PG LXV, en la tercera de las 7 catequesis (cf. Di Berardino, 2007, p. 3.568).

59 Vale recordar que el término latino nudus, yujvós en griego, no siempre indicaba una total desnudez; la expresión requeriría un contexto, porque en la antigüedad la completa desnudez solo implicaba la práctica del baño corporal, tan común en la cultura romana que frecuenta las termas y para los griegos amantes de los ejercicios lúdicos-atléticos: "үujvás", en tal caso (cf. Di Berardino, 2007, p. 3.568).

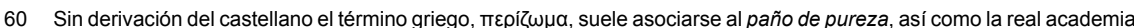
española de la lengua lo circunscribe al lenguaje de la pintura y la escultura: "en las representaciones religiosas, este paño cubre las partes pudendas de los cuerpos desnudos masculinos, especialmente de Cristo".

61 Solo en el capítulo X, 1, se dice: "salió Jesús del Pretorio, acompañado de dos bandidos. Llegó al sitio convenido, lo

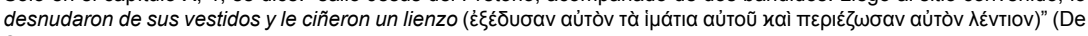
Santos, 1991, p. 415).

62 El obispo de la Galia merovingia conocía tan bien la literatura apócrifa, que él mismo manifiesta no conocer más que la primera parte de una obra que denomina Gesta Pilati al referir las escenas de la pasión (De Santos, 1991, p. 391). De las Gesta Pilati conservado en griego, en tiempos de Gregorio de Tours, se sabe que debió difundirse muy pronto en occidente puesto que lo cita con lujo de detalles en Gregorio de Tours, Historia Francorum I, 21. PL LXXI, 215 (cf. Mâle, 2001, p. 244).

63 "Cuius coniux basilicam sancti Stephani suburbano murorum ædificavit. Quam cum fucis colorum adornare velit, tenebat librum in sinum suum, legens historias actionis antiquæ, pictoribus indicans, quae in parietibus fingere deberent. Factum est autem quadam die, ut, sedente ea in basilica ac legente, adveniret quidam pauper ad orationem, et aspiciens eam in veste nigra, senio iam provecta, putavit esse unam de egentibus protulitque quadram panis et posuit in sinu eius et 
es el del Crucificado. Además, la Iglesia dedicada a San Esteban tendrá que aclararnos la verdad histórica de estos hechos, si se la estudia con este objeto, pero este dato más puede parecer un referente simbólico que representa a la institución eclesiástica en la persona de esta generosa dama -la segunda carta del Apóstol Juan (1:1) llama también a la Iglesia "electa kýria"- y el libro que lee en voz alta no podría ser otro más que las Sagradas Escrituras, a las que habría que seguir casi al pie de la letra cuando se las interpreta con imágenes para no distorsionarlas.

De tal modo interviene Gregorio de Tours, cuando establece la primera censura de la forma inconveniente e incorrecta de representar a Cristo en la cruz. En los ocho libros sobre los milagros -Miraculorum libri VIII-, refiere las noticias de una polémica obra de arte, un crucifijo, presente en la Iglesia Catedral de Narbona, no explícitamente desnudo pero de todos modos incómodo a su parecer para la contemplación de los fieles y naturalmente para la veneración de todos los que acudían a la Basílica:

En la basílica [Iglesia] principal, más antigua de Narbona, la cual se precia de tener las reliquias del bienaventurado mártir Genesio, se halla un cuadro que muestra a nuestro Señor crucificado y solo cubierto con un paño. Y como esta pintura estaba constantemente expuesta al público, un personaje terrible se le apareció en sueños a un cierto Basilio, que era sacerdote, y le dijo: "mientras ustedes siempre están cubiertos con muchos vestidos, permanentemente me ven desnudo: apresúrate y cúbreme con un vestido".

El sacerdote, quien no entendió la visión, no recordó detalle alguno de aquel día. Luego hubo otra aparición; pero este la considera insignificante. Al tercer día después de esta segunda aparición, el personaje, después de importunar con fuertes golpes, le dice al sacerdote: “¿Acaso no te había dicho que me cubrieras con un vestido, que no me dejaras desnudo a la vista de las personas? Y eso no lo has hecho. Ve y cubre con un paño [lienzo] ese cuadro en el que aparezco crucificado, si no quieres morir pronto".

Entonces, el sacerdote, asustado y lleno de temor, le contó al obispo lo sucedido, e inmediatamente, este ordenó ponerle un velo encima al cuadro. Y ahora se puede observar así, cubierto. Entonces, si se descubre el cuadro un momento para ser observado, inmediatamente se le pone el velo, para que no permanezca descubierto ${ }^{64}$.

abscessit. Illa vero non dedignans munus pauperis, qui personam eius non intellexit, accepit et gratias egit reposuitque, hanc suis epulis anteponens et benedictionem ex ea singulis diebus sumens, donec expensa est" (Gregorio de Tours, Historia Francorum II, 17. PL LXXI, 215). Gregorio, conocía bastante bien la literatura apócrifa, pues él mismo manifiesta conocer, en lo que se refiere a las escenas de la pasión de Cristo, la primera parte de una obra que denomina Gesta Pilati (De Santos, 1991, p. 391).

De su primer libro, escrito hacia el 593, encontramos: de crucifixo apud Narbonam: "est et apud Narbonensim urbem in eclesia seniore, quæ beati Genesii martyris reliquiis plaudit, pictura, quæ Dominum nostrum quasi præcinctum lenteo indicat crucifixum, quæ pictura dum assiduæ cerneretur a populis, apparuit cuidam Basileo presbitero per visum persona terribilis, dicens: "Omnes vos obtecti estis variis indumentis et me iugiter nudum aspicitis. Vade quantotius, operi me vestimento!" Et presbiter non intellegens visionem, data die nequaquam ex ea re memoratus est. Rursumque apparuit 
Algunos estudiosos del tema como Klaus Wessel $(1967)^{65}$ y L. Steinberg (Steinberg, 1989, pp. 159-160) entre otros, se inclinan a afirmar que, Gregorio de Tours no habría sido testigo de aquellos hechos. Posiblemente con la leyenda se creó una función representativa del Crucificado, dándole un carácter de teatralidad a la imagen, por cuenta del velo que se ponía y se corría, mientras se llevaban a cabo las funciones religiosas. Algo así como en los Auto Sacramentales ${ }^{66}$, tan difundidos e implementados durante la Contrarreforma.

¿Sería entonces la primera vez que la imagen del Crucificado podría haber jugado un papel tan protagónico en la liturgia, como se hace todavía en la liturgia del Viernes Santo? Cierto que la función del velo pretendía cubrir la anatomía del Crucificado, aunque de alguna manera ya estaba cubierta su desnudez: quasi præcinctum lenteo, decía el texto de Gregorio. El gesto de cubrir por entero la imagen, quería evitar el hecho de ver al Redentor derrotado, despojado y desnudo en la cruz. El horror y la crudeza de la crucifixión, pudieron resultar sensiblemente repugnantes para entonces (Thoby, 1959, p. 10), para esto servía la función del velo, además.

Como vemos, la importancia de este suceso de fines del siglo VI ya no radica en el propósito de fortalecer el aparato dogmático sobre la persona de Jesús, cosa que estaba ya muy bien definida ${ }^{67}$. El hecho tampoco quiere intervenir directamente la iconografía del Crucificado. Lo significativo, es la exigencia y la función del velo que cubre una imagen, cuya tipología desconocemos, pero que podría asociarse al modelo sabiniano-helenístico ${ }^{68}$, sobre el que triunfa una mirada moralista que censura su forma y su contenido, porque además ha perdido actualidad (Mellado, 1852, p. 806). Claramente no es una cuestión de gusto o disgusto:

Comporta una inversión de tradiciones a este punto consolidadas en el tiempo y la creación de un nuevo universo de imágenes incisivas como potentes [...] el cristianismo del siglo $\mathrm{V}$, caracterizado por la sistemática destrucción de templos paganos y de sus estatuas [...] heredó de la religión hebrea un profundo sentido de pudor como

ei; sed et illud parvi pendit. Post tertium autem diem secundæ visionis, gravibus excruciatum verberibus, ait: "Nonne dixeram tibi, ut operires me vestimento, ne cernerer nudus; et nihil ex hoc a te actum est ? Vade", inquid, "et tege lenteo picturam illam, in qua crucifixus appareo, ne tibi velox superveniat interitus". At ille commotus et valde metuens, narravit ea episcopo, qui protenus iussit desuper velum expandi. Et sic obtecta nunc pictura suspicitur. Nam etsi parumper detegatur ad contemplandum, mox dimisso velo contegitur, ne detecta cernatur" (Gregorio de Tours, In gloria Martyrum 23, PL LXXI, 724-725).

65 El pasaje -de ser histórico-, habría ocurrido un siglo atrás, de otro lado sería solo leyenda (cf. Wessel, 1967, pp. 333-345).

De fuerte auge en el siglo XVI y hasta su prohibición en 1765 (cf. Arellano y Duarte, 2003, p. 89).

"La autoridad del concilio Quinisexto, fue reconocida implícitamente por la confesión tácita de la iglesia latina; ello no obstante, la decisión relativa a la crucifixión prevaleció en toda la cristiandad aun antes que el papa Adriano la hubiese confirmado a fines del siglo VII. La censura de Gregorio de Tours en el siglo VI no hizo más que sancionar un uso que ya se había introducido en la cristiandad" (Mellado, 1852, pp. 806-807).

68 Para entonces ya era notable la presencia monástica oriental (siria) en Roma, tanto más en la provincia narbonense, lo que supone y explica que monjes y artistas hayan influido directamente en esta transformación (cf. Leclercq, 19071953, pp. 3.079-3.080) 
para mostrar públicamente el corpo desnudo tranquilamente en las termas romanas (Mathews, 2000, pp. 396-397).

Por el discurso anatómico, se llegó luego al problema de la desnudez, lo que fue haciendo cada vez más indispensable la presencia del paño de pudor. Se recurre -en sentido iconográfico- al uso del perizoma como estaba propuesto en el libro del Génesis ${ }^{69}$.

Estamos ante el paso de lo simbólico a lo realístico. El acercamiento a la veracidad histórica de la crucifixión requiere la presencia del paño de pudor, que antes no existía. Desde entonces, esta prenda cuyos usos, modas, colores y lujos varían, propone a su vez el regreso de otra lectura simbólica que ofrece la escena de la crucifixión, como lo estudia Larissa Bonfante en su obra ${ }^{70}$.

El paño de pudor desde entonces -y tan necesario en adelante-jugará un papel que no será tan superficial. A partir de las representaciones carolingias de la crucifixión, con el perizoma al puesto del subligaculum, Cristo seguirá siendo un luchador-vencedor, mientras las representaciones de Jesús vestido del colobio, no desaparecerán del todo, se confinarán a los espacios monásticos (figuras 16 y 17), pasando a un segundo plano (cf. Van Laarhoven, 1991, p. 85).

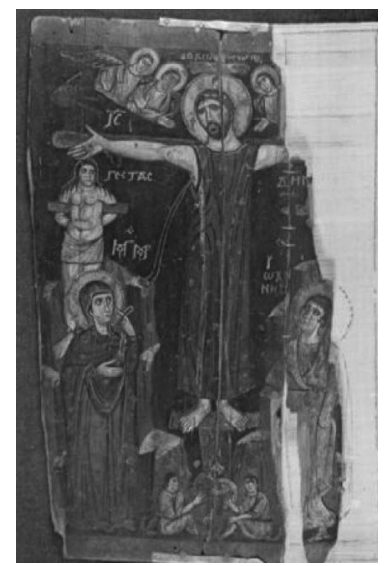

Figura 16. Icono anónimo del s. VIII. Crucificado vestido de colobium, monasterio de santa Catalina en el Sinaí.

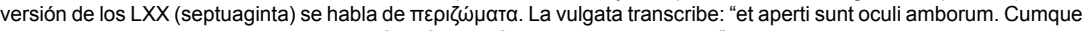
cognovissent esse se nudos, consuerunt folia ficus et fecerunt sibi perizomata". correa, botones, hebillas, cuerdas y otra serie de adornos que lleva el perizoma. Lo que puede determinar la condición y la dignidad de la persona que las viste: el rey o el esclavo (cf. Bonfante, 2003, pp. 19-31). 


\section{Una transparencia en el Medioevo}

La intervención de Gregorio de Tours oficializó, por así decirlo, la representación del perizoma o paño de pudor en la iconografía de la crucifixión. Sin embargo entre los siglos VI-VIII se alternarán todavía el modelo sabiniano y el sirio. En el monasterio de santa Catalina del Sinaí se conservan sendos ejemplos de estas dos tipologías, una de las cuales es la figura 16. También se alternan en la cantidad de manuscritos: evangeliarios, códices y salterios, en los que aparecen complementaria y simultáneamente ambas posibilidades iconográficas; claro que el vestido de colobium (figura 17) con menos frecuencia que el semidesnudo (figura 18), las dos grandes corrientes iconográficas del Medioevo: la helenística y la siria, como lo afirma Émile Mâle (Mâle, 2001, p. 224).

Ya en el alto y bajo Medioevo empieza a interesar un tipo de representación que va más allá de la forma cubierta o descubierta de la anatomía del Crucificado. Lo que empieza a importar gradualmente es la narrativa de las escenas de la crucifixión. A finales de los siglos VIII y IX, se reafirmó y se aprovechó, desde el punto de vista artístico, la doctrina que equiparaba el cuerpo sacramental de Cristo con el histórico (cf. Jászai, 1991-2002, p. 579). Superada la crisis iconoclasta $^{71}$, se refuerza y abunda toda esta iconografía ${ }^{72}$.

La representación semidesnuda de su anatomía se irá haciendo cada vez más dramática y realista como la fisonomía del rostro del Crucificado, identificando dos nuevas corrientes. De una parte está la bizantina-oriental, representada en el Logos inmortal, el Christus vigilans, de ojos muy despiertos, ya presente desde el primer arte cristiano pero que perdurará hasta después del primer milenio, como se puede notar en la cruz de marfil de Fernando y Sancha, del año 1063 (Franco, 1991, pp. 35-68; figura 19); en la pintura mural de Sant'Angelo in Formis, decorada alrededor del año 1073 (figura 20), hasta el famoso crucifijo de san Damián fechado en torno al 1100 (figura 21). De otra parte aparecerá la forma típica occidental, con mayor dramatismo en la solución anatómica del cuerpo y tanto mayor cuidado en el tratamiento del rostro, con los ojos cerrados como gestualidad que quiere subrayar la muerte del Verbo (cf. Grondijs, 1947, p. 130).

71 Este espinoso, sombrío y complejo problema (del 726 o 730 al 843) no surgió de un edicto imperial (730) sobre las imágenes, fue el llamado eclesiástico que convocó al pueblo a darles el justo valor. Cierto que en el año 726, León III el sirio, tomó la iniciativa retirando el icono de Cristo de la puerta de bronce del palacio, reemplazándola por una cruz desnuda (cf. Jedin, 1970, pp. 91-92).

72 La fortaleza doctrinal de las imágenes estriba en los cánones del Concilio de Nicea II (DZ, p. 603), en la doctrina de san Juan Damasceno: "es lícito hacer una imagen de todo cuanto se ha visto de Dios" discurso sobre las imágenes I, 16 PG XCIV, 1234-1420; en la de san Gregorio Magno: "in ipsa legunt qui litteras nesciunt", Epistola XIII Ad Serenum massiliensem episcopum PL LXXVII, 1128; y en los Libri Carolini "Christi imaginem honorandam sicut et imaginem imperatoris Pater sensit" (cf. Gero, 1973, p. 12). 


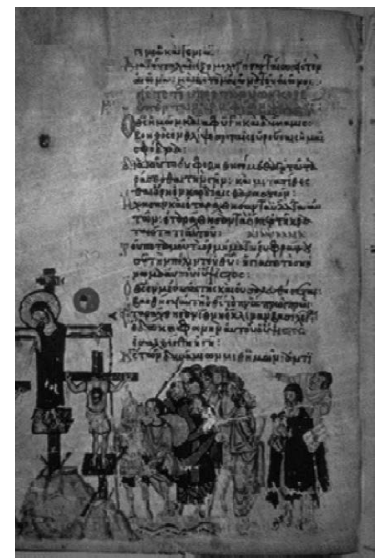

Figura 17. Cristo vestido de Colobium. Salterio Chludov, folio 45, 850 ca.

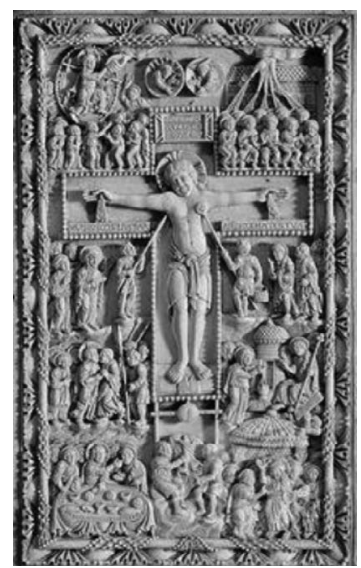

Figura 18. Marfil carolingio anónimo del s. IX, Catedral de San Justo, Narbona, Francia.

En lo relativo a la desnudez, no sabríamos determinar con precisión si el Medioevo es decididamente tímido, temeroso o indiferente, pues -como es clásico de la semántica cristiana- el desnudo solo se consiente cuando el tema sacro lo requiere. Para el artista que trabaja exclusivamente en las iglesias o que ilustra los códices monásticos, en gran parte se le concede espacio a la fantasía, pero tiene muchos "sens interdits", uno de ellos: la desnudez. En otros ambientes y posibilidades, contaba con tanta mayor libertad para crear sus obras (cf. Fossi, 1999, p. 60).

Lo que sí es claro durante el Medioevo es el tratamiento casi metafísico -irrealde la figura humana. Ello no quiere decir que no fueran menos estudiados los cánones anatómicos. La paradoja está en Villard de Honnecourt (muerto ca. 
1250) ${ }^{73}$ y en Hildegarda de Bingen (1098-1179) ${ }^{74}$. Estos empeñados estudios de la anatomía, no harán aportes a la representación del cuerpo, que seguirá siendo ingenua e imprecisa; de una parte porque pesa aún el valor de la estética neoplatónica, anti-clásica, propia para mirar con ojos de espíritu las cosas invisibles (Grabar, 2007, p. 25); de otra parte porque el cuerpo en el Medioevo como afirma Jacques Le Goff "no es ni oscuro ni áureo"75.

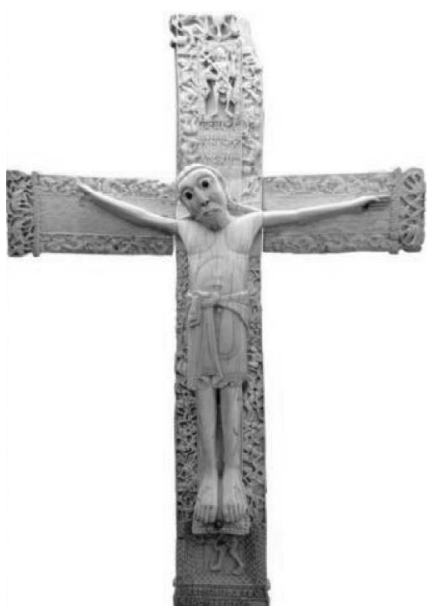

Figura 19. Anónimo español.

Crucificado de don Fernando y doña Sancha, hacia 1060,

Museo Arqueológico de Madrid.

Los artistas-artesanos medievales, estaban muy lejos de los cánones griegos, a la hora de resolver la anatomía del Crucificado en la cruz, pero no del cuidado en variar de mil formas el drapeado, convirtiendo el perizoma con el correr del tiempo en un elemento plástico recurrente que nunca dejará de ser expresivo ${ }^{76}$, pese a que algunos estudiosos lo sigan mirando indudablemente como "una convención que solo se justificaba por escrúpulo de decencia del cual pocos artistas se atrevieron a librarse" (Réau, 2000, p. 498).

73 Este arquitecto viajero demostró en su Livre de portraiture, concretamente en el MS. fr. 19.093, fol. 18 y MS. fr. 19.093, fol. 19 de la Bibliothèque Nationale de París, que el cuerpo en el Medioevo se lo comprende "pour légièrement ouvrier" a través de la geometría.

74 En la cuarta visión del primer libro (Liber divinorum operum simplicis hominis I, IV, 49 PL 197, 840) Hildegarda de Bingen abunda en consideraciones algo más que anatómicas; recurriendo a la armónica idea vitruviana, advierte que ese cuerpo es un pequeño cosmos proporcionado y como creación de Dios refleja la armonía del Universo..

75 "Mientras se asiste al desplome de las práticas corpóreas y al tiempo a la supresión o marginalización de los espacios dedicados al cuerpo en el mundo antiguo, el cuerpo deviene paradójicamente el centro de la sociedad medieval [...]. De un lado la ideología del cristianismo, ya religión de Estado, reprime el cuerpo; de otro lado, con la Encarnación de Dios en Cristo, el cuerpo del hombre deviene "tabernáculo del Espíritu Santo" (Le Goff, 2005, p. 19).

76 Las volutas del paño de pudor a derecha e izquierda se vuelven tan complejas como las líneas de un párrafo caligráfico: "Lendenschurz" las Ilama la tradición alemana (cf. Réau, 2000, p. 499). 
Hasta el siglo XIII, el paño de pudor puso en juego, no sola el talento de los artistas sino mejor aún una novedosa semántica como nunca antes se conoció en la plástica cristiana.

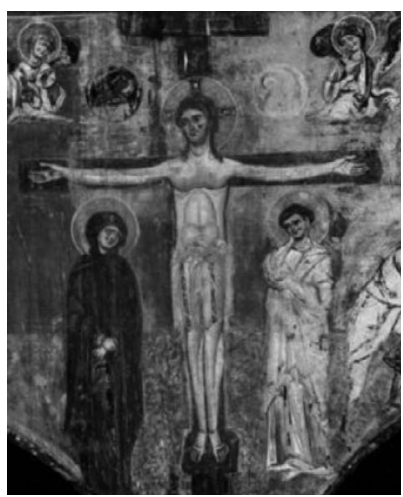

Figura 20. Cristo entre María y san Juan.

Pared izquierda anónimo del s. XI.

Sant'Angelo in Formis, Capua, Italia.

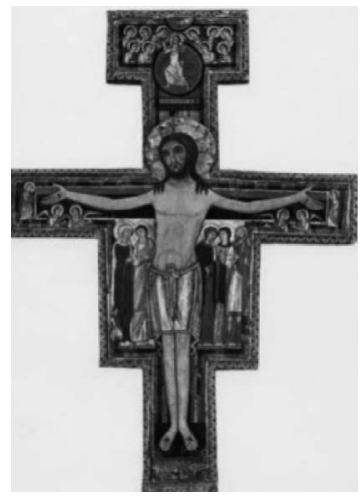

Figura 21. Crucifijo de san Damián. Anónimo del s. XI, Monasterio de santa Clara, Asís, Italia.

La espiritualidad franciscana como decíamos en la segunda parte "convertirá el cuerpo en un vehículo controlado y canonizado de lo divino" (Clark, 2008, p. 226) sobrevalorando el concepto de la desnudez a la que no ha renunciado el pensamiento cristiano del Medioevo para darle una nueva fuerza: "un hombre vestido no puede luchar con otro que está desnudo porque lo derriba pronto, teniendo por donde asirlo" dice Francisco (1182-1226) a Clara de Asís (1194-1253). Ella a su vez, convertirá este pensamiento en un referente, como lo transparenta la carta que escribió a la beata Inés de Praga, con esos mismos sentimientos ${ }^{77}$.

77 La primera carta estaría fechada antes del 11 de junio de 1234: "et vestitum cum nudo certare non posse, quia citius ad terram deicitur, qui habet unde teneatur" (Menestò, 1995, p. 2285). 
El misticismo sentimental de estos amigos, traerá consecuentemente el beneficio de emancipar a la estética medieval de los patrones bizantinos que por ejemplo glorificaba el Crucificado conservándolo vivo, como hemos dicho.

"El arte franciscano es el polo opuesto de la elegancia impersonal y "oficial" del arte bizantino que empezaba a pasar de moda"78; el Jesús de Francisco es el de Nazaret: hombre pobre, nacido de una madre pobre. Es un desnudo a quien solo desnudo se puede seguir ${ }^{79}$.

Lo confirma Buenaventura de Bagnoreggio, en este retrato de Francisco, en la Legenda Maior:

Ciertamente, [Francisco] quiso conformarse en todo con Cristo crucificado, que estuvo colgado en la cruz: pobre, doliente y desnudo. Por esto, al principio de su conversión permaneció desnudo ante el obispo, y, asimismo, al término de su vida quiso salir desnudo de este mundo. $\mathrm{Y}$ a los hermanos que le asistían les mandó por obediencia de caridad que, cuando le viesen ya muerto, le dejasen yacer desnudo sobre la tierra tanto espacio de tiempo cuanto necesita una persona para recorrer pausadamente una milla de camino ${ }^{80}$.

Resulta entonces lógico que, Giotto di Bondone (1267-1337) ${ }^{81}$, o quizás con más anterioridad Cimabue (1240-1302), hayan sido los primeros responsables en concretizar las líneas basilares de la incipiente estética franciscana que valoraba en tal manera la condición humana que nunca desdeñó Cristo como para representarlo sobresalientemente humano: “descargó todos sus vestidos, incluso tiró su ropa interior, ebrio de espíritu, no temió desnudarse totalmente por amor de Aquél quien por nosotros colgó desnudo de la cruz" 82 .

78 "El arte franciscano está en el polo opuesto de la elegancia impersonal y "oficial" del arte bizantino que entonces pasaba de moda" (Verdon, 2009, p. 71).

79 El franciscanismo bebió directamente del pensamiento de los Padres de la Iglesia "Nudus Christum nudum" (desnudo a Cristo desnudo), San Jerónimo, Epistula ad Rusticum monachum 125,20 PL XXII, 1085; él mismo escribe: "nudam crucem, nudus sequi" Epistula ad Hedybiam de questionibus duodecim 120,1 PL XXII, 985; lo repite en Epistula ad Nepotianum presbyterum 52,5 PL XXII, 531; Epistula ad Paulinum presbyterum 58, 2 PL XXII, 580; pero también de Casiano (ca. 365-ca. 435) afirma: "universis divitiis mundi, perfectam Christi præferunt nuditatem" (los que prefieren a todas las riquezas la perfecta desnudez de Cristo), Casiano, Collationes XVIII, 7 PL XLIX, 1104; "quod et perfectam nuditatem Christi universarum rerum suarum abjectione possideat" (habiendo renunciado a toda su fortuna, posea la perfecta desnudez de Cristo) Cœnobiorum Institutis X, 19 PL XLIX, 385.

80 "Voluit certe per omnia Christo crucifixo esse conformis, qui pauper et dolens et nudus in cruce pependit. Propter quod et in principio conversionis suæ nudus remansit coram antistite et consummatione vitæ nudus voluit de mundo exire, fratribusque sibi assistentibus in obœdientia caritatis iniunxit, ut, cum viderent eum iam esse defunctum, per tam longum spatium nudum super humum iacere permitterent, quod unius milliari tractum suaviter quis perficere posset" Buenaventura de Bagnoreggio, Legenda Maior XIV, 4 :5-7.

81 Vasari reporta el primer crucifijo de Giotto en la Iglesia de Sta. Ma. Novella de Florencia entorno 1390-1400 (cf. Vasari, 1928, p. 301).

82 "Quin potius vestimenta sic cuncta deposuit, quod et femoralia ipsa reiecit totusque coram adstantibus, ut ebrius spiritu, amore illius nudari non horruit, qui nudus pro nobis in cruce pependit" (Buenaventura de Bagnoreggio, Legenda Minor I, 7, 1.336). 
Con toda probabilidad Giotto, por su responsabilidad en la tarea de decorar la Basílica de Asís (1290-1295), es quien mejor interpreta en su pintura la espiritualidad que Francisco hubiera querido encontrar y transmitir en su Crucificado ${ }^{83}$. Es a partir de Giotto, que un simple velo de transparencia a guisa de paño de pudor ceñirá la desnudez del Crucificado. Ningún otro pintor antes de él usó este lenguaje ${ }^{84}$. Esta solución plástica, inaugurada por Giotto (figura 22), respetará la tradición iconográfica -del perizoma- sin desvestir completamente la imagen del Crucificado pero poniendo en mayor evidencia la nueva posibilidad de la desnudez, que no es cruda anatomía. Aquí se entiende en el mejor de los sentidos:

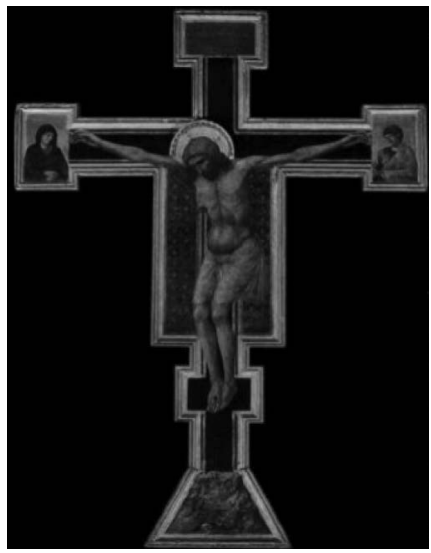

Figura 22. Giotto di Bondone.

Crucificado de santa Maria Novella. 1290 ca.

Le ofrecieron [a Francisco] el manto pobre de un vil campesino, siervo del obispo. Recibiéndolo con gratitud, trazó con su mano el signo de la cruz con una piedra que allí encontró y formó con ello un vestido como el que sirve a cubrir un crucifijo semidesnudo; así el servidor del Rey altísimo fue desnudado para que siguiera desnudo a Cristo desnudo crucificado, objeto de su amor ${ }^{85}$.

Naturalmente esta visión no tiene todavía la elocuencia del Renacimiento Humanista que presentará completamente desnuda la figura de Jesús en la cruz, aquí apenas se anuncia. Este velo-transparencia ${ }^{86}$, inicialmente no será tan

83 En el arte del primer franciscanismo no solo el cuerpo, todo el ámbito de la experiencia corpórea: el mundo, la naturaleza, lo cotidiano, adquiere una importancia sacral y de suyo indespreciable (cf. Verdon, 2009, p. 65).

84 Recordamos que E. Panofsky (2006, pp. 175-235), trata el tema en el capítulo 3: "I primi lumi”, declarando que la pintura del Trecento italiano impactará el resto de la pintura europea, como se advertía ya en Giotto, como precursor de los albores del Renacimiento Humanista.

"Oblatus est autem ei mantellus pauper et vilis cuiusdam agricolæ serventis episcopi, quem, ipse gratanter suscipiens, cum cæmento quod sibi occurrit, ad modum crucis manu propia consignavit operimentum formans ex eo crucifixit hominis et pauper seminudi; sic igitur servus Regis altissimi nudus relictus est, ut nudum sequeretur crucifixum Dominum, quem amabat" (Buenaventura de Bagnoreggio, Legenda Maior, II, 4). 
marcado en la escultura como en la pintura de finales del siglo XIII ${ }^{87}$. Pero sí podemos afirmar con este significativo número de artistas, que al menos hasta la primera mitad del siglo XVI (figuras 23 y 24) se crea efectivamente un pathosformel, un leitmotiv de recurso iconográfico.

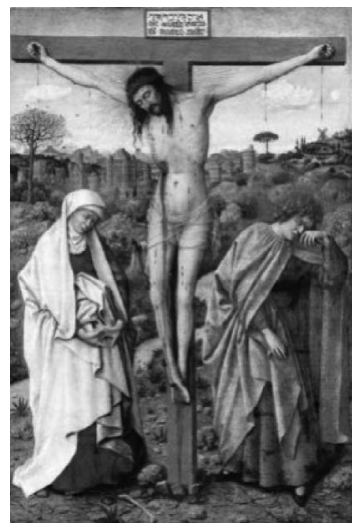

Figura 23. Hubert van Eyck. Crucifixión. Galeria Gemalde, Berlín. 1430.

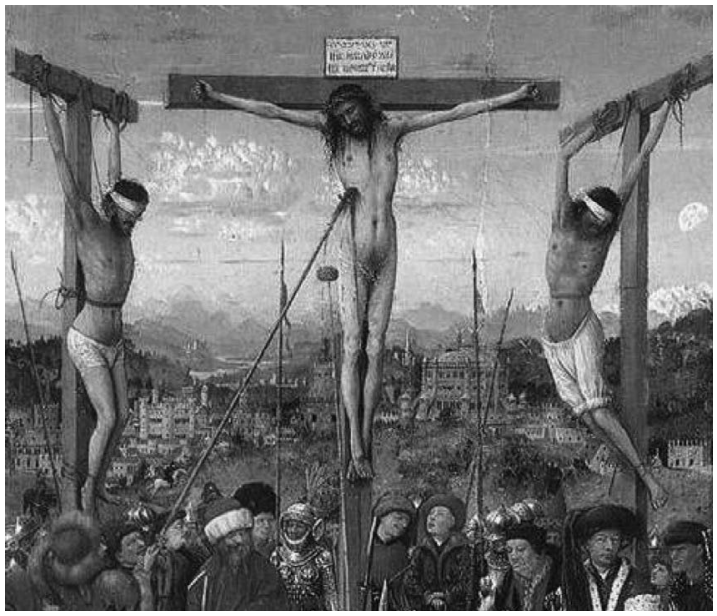

Figura 24. Jan van Eyck. Detalle del díptico de la Crucifixión. 1420-1425. Museo Metropolitano de New York.

87 Por lo menos durante todo el siglo XIV este patrón iconográfico lo usaron Duccio de Boninsegna (ca. 1255-1319), Simone Martini (ca. 1285-1344), Bernardo Daddi (ca. 1280-1348), Lippo Memmi (ca. 1290-1347), Pacino de Buonaguida (activo ca. 1303-1340), Ugolino de Nerio (ca. 1317-1330) Pietro de Rímini (activo 1324-1338), Nicolò de Buonaccorso (activo ca. 1348-1388), Simone de Filippo o dei crocifissi (ca. 1330-1399), Luca de Tommè (ca. 1330-1390), Paolo Veneziano (ca. 1300-1362), Taddeo (ca. 1300-1366) y Agnolo Gaddi (ca. 1345-1396), Roberto d'Oderisio (activo en Nápoles ca. 1335-1382), Giovanni de Milano (activo 1350-1369), Maestro del Códice de san Jorge (activo en Florencia 1325-1350), Maestro de Hohenfurth (activo en Praga 1350-1370), Maestro de san Marcos (catalán activo 1355-1360), Jacobello Alberegno (muerto no antes de 1397), Nardo de Cione (activo ca. 1343-1365), Paolo de Giovanni Fei (ca. 1345-1411), Mariotto de Nardo (activo ca. 1394-1424), Jean de Beaumetz (activo 1361-1396), entre muchos otros incluso no italianos pero siempre en el arco de este siglo. 
Este tipo de crucifixión de iniciativa franciscana (figura 25) pasa a ser impulsado por la espiritualidad dominicana (figura 26) puesto que también son fruto del mismo fenómeno mendicante medieval. El caso del velo que re-vela, que viste para desvestir ${ }^{88}$, filtra la luz para hacerla un tanto más perceptible. Logra ser intermediario para acceder a un no conocimiento particular (Chevalier y Gheerbrant, 2000, p. 1.238) ${ }^{89}$ : al pleno conocimiento, el del Cristo completo y entero: Dios y Hombre a la vez.

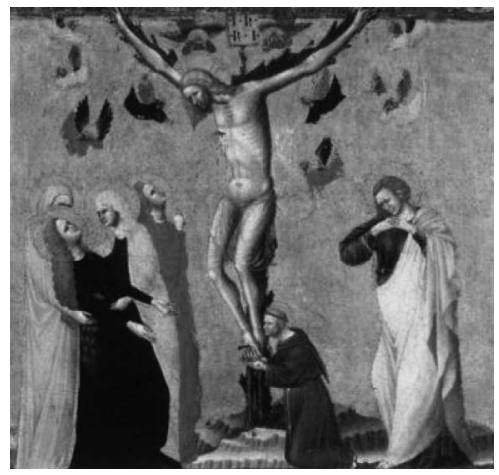

Figura 25. Escuela italiana desconocida ¿Roberto d'Oderisio?

Cristo en la Cruz con monje franciscano,

Museo Fesch, Ajaccio. 1340.

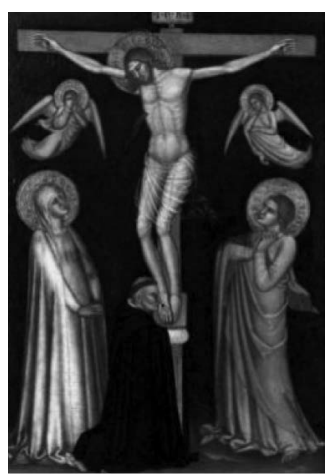

Figura 26. Andrea da Firenze.

Cristo en la Cruz con santo Domingo,

Pinacoteca vaticana, 1370-77.

Esta anatomía de Cristo, entre desnudo y velado, representa justamente al hombre hecho de tierra, al hombre liberado del peso o de la atadura de la materia.

Característico incluso todavía en el Quattrocento, según anota L. Steinberg (1989, p. 181).

89 También en la iconografía hindú el desvelamiento del cuerpo humano simboliza el acceso al conocimiento, lo cual es muy afín a la valoración neoplatónica de la desnudez, representante a su vez de los conceptos de la autenticidad y de la verdad (cf. Revilla, 2007, p. 619). 
Este hombre colgado y desnudo en la cruz, es también modelo de la figura del hombre espiritual por excelencia al final del Medievo: simbólico y espiritual (Beigbeder, 1995, p. 162).

Este tipo de estética, que acompañará la pintura del Quattrocento y del Cinquecento en el norte de Europa representará con mayor fuerza expresiva la exclamación de Job: "nudus egressus sum de utero matris meæ et nudus revertat illuc" ("desnudo salí del vientre de mi madre y desnudo volveré allí"), que ya introducíamos en la segunda parte de este trabajo, y representa con mayor armonía la iconografía del Nacimiento de Jesús, en que aparece puesto en la tierra y desnudo el recién nacido.

Pero hay otros elementos más significativos y simbólicos todavía que se pueden explorar en la difusión de este tipo de representación iconográfica, como las expone L. Steinberg.

Las escenas de la crucifixión, en que la sangre brota del costado abierto, desciende en hilos verticales y se infiltra por el muslo hasta llegar a sus partes viriles, suelen asociarse al modelo que une la última y la primera herida la lanzada y la circuncisión del cuerpo de Cristo (figura 27). Entonces no es la Pasión que sufrió en Jerusalén; es la vida entera de Jesús que está marcada y es leída en clave de salvación.

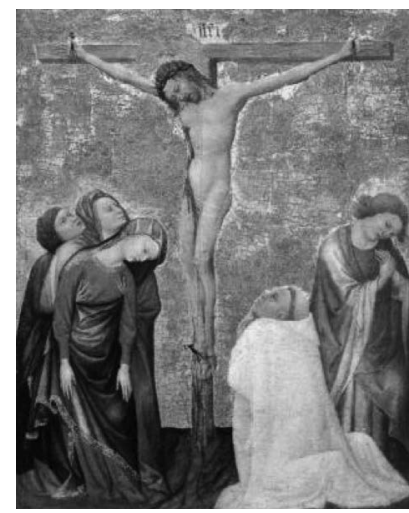

Figura 27. Jean de Beaumetz. Cristo en la cruz con monje cartujo, Museo del Louvre, París. 1389-95.

L. Steinberg con otro punto de vista sugiere que hagamos una lectura que podría estar escondida en este tipo de representaciones. En los mismos temas iconográficos que podrían ser exvotos penitenciales. Apenas podemos sospecharlo. También son muy marcados los gestos de arrepentimiento y de expiación de monjes o clérigos que quebrantaban sus votos de castidad. Teniendo la oportunidad de hacer penitencia -ayudados con este tipo de imágenes o ¿comisionándolas?- alcanzaban así el perdón de sus pecados (cf. Steinberg, 1989, pp. 187-188). 


\section{El Crucificado desnudo en la leyenda y en la mística}

Como declara É. Mâle en uno de sus estudios iconográficos (2001):

Los Evangelios eran demasiado breves y las comunidades cristianas no quisieron resignarse a su silencio [...]. El deseo de adivinar la vida oculta de Jesús lo encontramos en todos los tiempos. Las Meditaciones del pseudo Buenaventura ${ }^{90}$, las revelaciones de santa Brígida de Suecia, de María Ágreda y los asombrosos relatos de Ana Catalina Emmerich ${ }^{91}$ nos demuestran que la tierna curiosidad que hizo nacer los evangelios apócrifos no ha desaparecido ni siquiera en nuestros días (pp. 242-243).

Efectivamente la plástica del siglo XIII y XIV todavía se nutría de esta enorme fuente de la iconografía al margen de las Sagradas Escrituras siempre tan abundantes en imágenes como inagotables de significados. Sin embargo, en La Leyenda Dorada Santiago de la Vorágine (1228-1298) no aborda el tema de la desnudez de Cristo en la cruz ${ }^{92}$. Se limita a confirmar los testimonios del evangelio de Nicodemo que ya citamos (recuérdese la nota 296). Otra obra de importante responsabilidad en el imaginario de esta época es la Devotio Moderna: una espiritualidad aireada por fuera de los monasterios, altamente contemplativa, nada especulativa y sobre todo crítica $^{93}$. Pero, esta religiosidad privada de la segunda mitad del siglo XIV, tampoco alcanzó a impactar fuertemente el imaginario de entonces, recreando escenas significativas de la crucifixión de Jesús.

El siglo XV recibe generosas contribuciones de la literatura espiritual como: el Speculum Humanæ Salvationis ${ }^{94}$ y la Biblia Pauperum ${ }^{95}$ y, junto a estas: el Speculum

90 Especialmente los capítulos LXXVIII y LXXIX que se refieren a la crucifixión (cf. Cellucci, 1938, p. 47).

91 Esta mística alemana (1774-1824) aunque es posterior a este periodo que analizamos, se une a la tradición -como nota É. Mâle- que abunda en imágenes de la pasión. Por ejemplo, en el capítulo VIII: "el Señor, temblando, se quedó con un paño ceñido a la cintura y el manot de lana que lo protegía en las espaldas, el mismo que se le había pegado a las llagas de la espalda. Sufrió dolores destrozantes justo cuando se lo arrancaron. El cuerpo desnudo de Jesús era horriblemente desfigurado [...]. Entretanto su madre quedaba inmersa en una ardiante plegaria, estaba pensando precipitarse sobre su Hijo para cubrirlo con su propio velo, cuando vio que Dios la escuchó: en aquel mismo instante un hombre salido de la multitud se lanzó a los pies de Jesús y lo cubrió con un lino, con el que Jesús, luego de haberle agradecido, se envolvió la cintura" (Ana Catalina Emmerick, 2005, pp. 259-260).

92 La Leyenda Dorada no ofrece mayores detalles que pudieran inspirar una particular manera de representar a Jesús en la cruz, los capítulos de la Invención y tanto más de la Exaltación de la Cruz se limitan a detalles de tipo legendario como la imagen que elabora Nicodemo, más conocida como volto santo (cf. De La Vorágine, 1982, p. 588).

De los ocho rasgos típicos que Villoslada expone en su artículo, sobre todo puede haber incidido mucho: el cristocentrismo práctico, el moralismo, el carácter afectivo y la interioridad que definen la fisonomía espiritual de la Devotio Moderna en relación a nuestro tema iconográfico (cf. García 1956, p. 317).

94 Ligeras variaciones en la lectura tipológica de las 34 escenas del Antiguo y el Nuevo Testamento de la edición inicial; cuando representa al crucificado suele referirlo a la condición edémica de los primeros padres Adán y Eva en razón de la redención por la muerte de Jesús en la cruz, no porque aluda a la desnudez paradisíaca de Cristo nuevo Adán propuesta en Pablo: Rom. 5:12-21; 1 Cor. 15:21-22 (cf. Van Laarhoven, 1991, pp. 325-327; Sebastián, 2009, pp. 359-367).

95 Esta ayuda no solo respondía a la ignorancia del clero o del pueblo, "tante di queste opere esegetiche che teologiche, la maggior parte di difficile rappresentazione ma di utile raffigurazione da porre problema pratici, il loro uso sembrava limitarsi alla letteratura. Pittori e scultori dovettero operare una selezione acuratissima a scopo di giungere il fine illustrativo delle scene" (Van Laarhoven, 1991, pp. 117-118). 
Anime ${ }^{96}$, la Concordantia Caritatis, la Historia Scholastica de Pedro Comestor y el Speculum historialæ de Vicente de Beauvais ${ }^{97}$. Sin embargo, este significativo aporte literario, solo conoce algunas ilustraciones en libros con el tema de la desnudez de Cristo en la cruz (figura 28). Lo que significa que, si los manuales de vida espiritual no abundaran en este tipo de imágenes, al menos difundían la ostentatio genitalium -expresión que acuña L. Steinberg- y que solo alcanzará completamente su valor estético y teológico en el Renacimiento Humanista, ya despertándose en el tardo Medioevo.

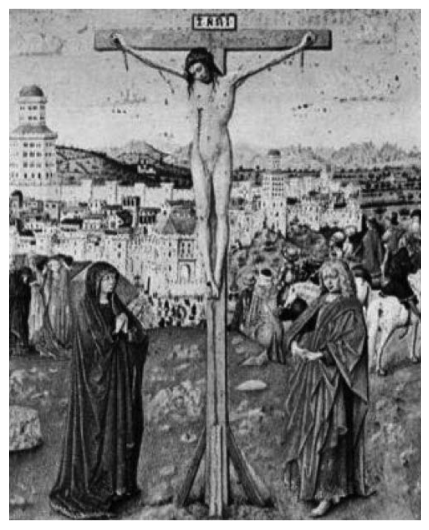

Figura 28. Miniaturista nerlandés.

Página de las más bellas horas de Notre Dame de Jean de Berry, Museo Civico de Arte Antigua, Palazzo Madama, Turín, Italia, 1400.

Las fuentes, legendarias y místicas del bajo Medioevo, ya cercanas a las luces del Renacimiento, de manera progresiva van reforzando con mayor seguridad la idea de representar a Jesús desnudo en su pasión; especialmente en las escenas que van antes del suplicio de la crucifixión, durante la flagelación y en algunos casos más extraordinarios en el momento mismo de la crucifixión. Esa espiritualidad de la desnudez, se hace cada vez más fuerte y sobre todo en los místicos de corriente franciscana, como Ángela de Foligno (1248-1309) mística que se abandona desnuda a la cruz, en señal de su conversión ${ }^{98}$.

Al margen del franciscanismo, pero en la misma línea, Brígida de Suecia en sus escritos, acentúa la crueldad del suplicio y la pena por la desnudez de Jesús antes de ser llevado a la cruz:

El manuscrito de origen valenciano equivocadamente atribuido a sor Isabel de Villena quien realmente escribió la Vita Christi, en términos generales responde a la serie de obras que giran alrededor de la pasión de Cristo y de María asociada a ella, buscando despertar la piedad y la compasión de los fieles mediante imágenes expresivas y conmovedoras, de ahí el uso y sobre todo su difusión a partir del siglo XIV hasta fines del XVI (cf. Sebastián, 2009, p. 404). sistematizada a inicios del XIII (cf. Mâle, 2001, p. 257). escribe: "et nuda irem ad crucem"; ella, que ha representando y sugerido tal idea ya, decía ante la visión de la crucifixión: "expoliavi me omnia vestimenta mea et totam me obtuli ei" (Pásztor, 2000, pp. 279-280). 
Él mismo [para ser flagelado] se desvistió de sus vestidos, [...] no tenía nada que lo cubriese, [...] estaba así como había nacido, sufriendo la vergüenza de la desnudez [...]. Estando allí [en el calvario] como había nacido en cuerpo desnudo, alguien corrió a llevarle un velo, y él, enteramente contento se cubrió sus intimidades [figura 29] ${ }^{99}$.

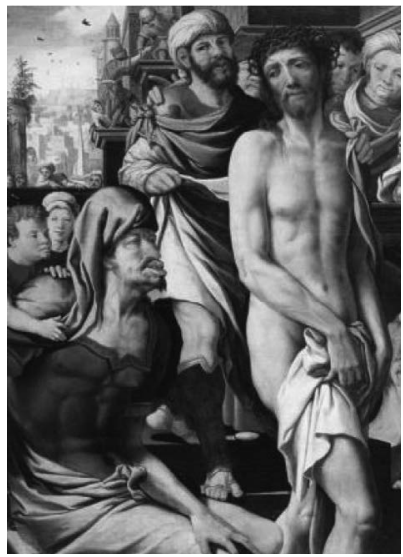

Figura 29. Jan Sanders van Hemessen, Cristo burlado, Museo de la cartuja de Douai, 1560.

Esa idea de alguien que corre a cubrir la desnudez de Jesús, o cuando él mismo se cubre, contrasta con la idea franciscana que camina hacia la desnudez buscándola mientras esta espiritualidad huye de ella, atemorizada por el sentimiento de vergüenza, de recato moral, no alcanza a contemplar en la desnudez un ideal de perfección espiritual, como lo puede reflejar claramente estas obras.

En todo caso esto genera un tema iconográfico nunca antes visto: la madre de Jesús, se arrebata el velo de su cabeza para cubrir la desnudez de su Hijo colgado en la cruz: "el paño de mi cabeza le cubrió su cintura", escribía Dionisio Cartujano (1402-1471) ${ }^{100}$. La novedad se nota puesto que no es posible todavía encontrar otros referentes iconográficos anteriores a los dos particulares más importantes que hasta ahora se conocen. El primero, hacia 1440 (figura 30) pintado por Hans Hirtz (ca. 1410-1466) de la escuela de Estrasburgo. El más posterior, hacia 1520 (figura 31), pintado por el alemán Bernhard Strigel (1460-1528). Nada tienen que ver con la Reforma Protestante, apenas iniciada en 1517, y las disposiciones o censuras emanadas por el Concilio de Trento en

Liber, Caput I, 10: "rex glorie et angelorum, pannis vilibus indutus fui, ad columpnam nudus stabam, omnia obprobria et derisiones audiui auribus meis". X, 16: "Alligatus autem nichil omnino operimenti habebat sed, sicut natus est, sic stabat et paciebatur erubescenciam nuditatis sue"; 22 : "Stante autem filio meo, sicut natus erat, nudo corpore, unus tunc accurrens apportauit sibi velamen, quo ipse exultans intime velabat verecundiora sua"; LIX, 37: "Ego non erubui illam contemptibilem mortem pro eis. Ego, sicut natus fui, nudus stabam ante oculos inimicorum meorum" (Brigida Di Svezia, 1982, p. 27). No es de extrañar que el Cristo burlado de Jan Sanders van Hemessen, pintado en 1560, que hace parte del Museo de la cartuja de Douai, esté influenciado por esta espiritualidad.

100 "Panniculo capitis mei circumligavi lumbos eius" (Réau, 2000, p. 491). 
1545 y en 1563, con este tipo de iconografía que se inspira en los escritos del Pseudo-Buenaventura ${ }^{101}$ y en los de Ludolfo Cartujano, quien escribe su obra hacia $1350^{102}$. Sin embargo el tema que pudo propagar estas sensuras durante la Contrarreforma no aparecerá más allá de 1530.

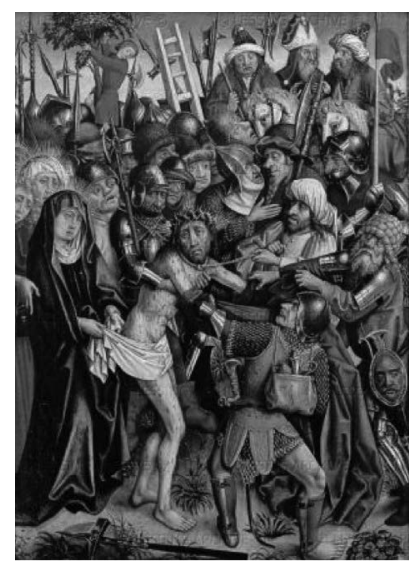

Figura 30. Maestro Karlsruhe-Passion ¿Hans Hirtz?

Cristo llevado al Gólgota, 1450ca.

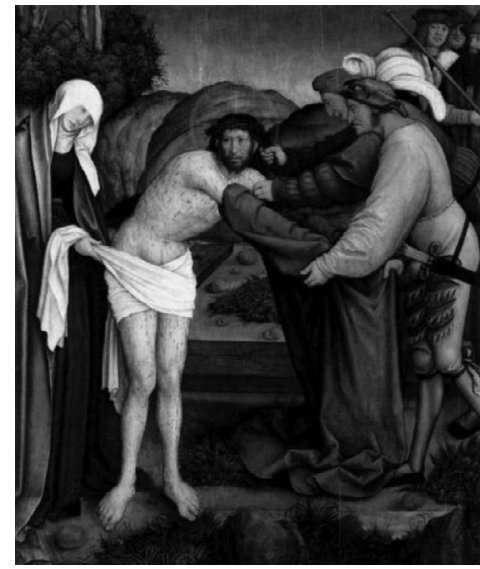

Figura 31. Bernhard Strigel. Espolio de Christ, 1520.

Ya que nos acercamos al tema del Renacimiento cabe aclarar que el relieve del púlpito de Bautisterio de Pisa (figura 32) llevado a cabo hacia 1260 y en donde

101 "Triste y llena de vergüenza más allá de toda misura, al contemplarlo enteramente desnudo, [pues] ni siquiera le dejaron su ceñidor [¿perizoma?], se apresura y se acerca, lo abraza y lo envuelve con el velo que pende de su cabeza" (Steinberg, 1989, p. 46).

102 El capítulo LXIII de la Passio Christi solo habla específicamente del hecho en cuestión. Émile Mâle sitúa la muerte del autor probablemente hacia 1378, en modo de no postergar equivocadamente el influjo de sus escritos (Mâle, 2001, p. 286). 
Nicola Pisano (ca. 1220-1284) habría recurrido al arte clásico, tornando la mirada atentamente a la naturaleza, "empezando a emplear el desnudo en su significación más noble" (Revilla, 2007, 183), anticipó las luces del humanismo, "sin que todavía estuviese suficientemente preparado para conseguir de ello generoso provecho" (cf. Thode, 1993, p. 445).

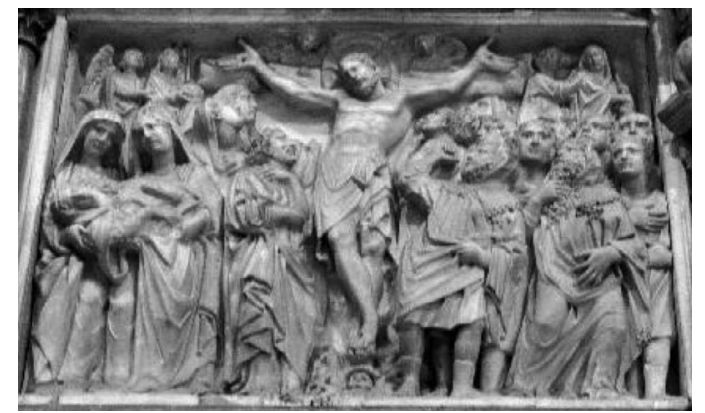

Figura 32. Nicola Pisano. Crucifixión, Púlpito del Bautisterio de Pisa, Italia, 1260.

\section{II \\ Delicatissimo, et in tutte le parti il più perfetto uomo"}

Filippo Brunelleschi (1377-1446) esculpe en 1410 un Cristo crucificado como nunca antes se había intentado ${ }^{103}$. Así está desde 1572 delante del altar de la Capilla Gondi ${ }^{104}$. En realidad un siglo antes, hacia 1310, ya en los círculos de Giotto en Italia así como en Francia y Bohemia, se estaba incursionando tímidamente con una iconografía totalmente desnuda de Jesús, primero la del niño y luego la del Crucificado (Steinberg, 1989, p. 44). Nunca fue comisionado y que hasta un año antes de su muerte permaneció en su casa cuando fue donado a los Dominicos de la Iglesia de santa María Novella en Florencia (figura 33), para adornar el muro que está entre la capilla Strozzi y la Bardi, donde todavía hoy son visibles los pernos que lo sostuvieron. La noticia de esta escultura en madera surge como la respuesta a la crítica que hizo Brunelleschi al crucifijo, o mejor al campesino que Donatello esculpió con

\footnotetext{
103 La suya sería "la primera obra renacentista en la historia del arte" (Bellosi, Cavazzini y Galli, 2002, p. 94). Considerando, además, que el silencio de C. Cennini lo rompería en $1436 \mathrm{~L}$. B. Alberti, primer tratadista empeñado en la construcción de la figura humana en el Renacimiento, superando los intentos esquemáticos de Hildegarda de Bingen, Villard de Honnecourt en el Medioevo, en el De Pictura, 36, dice: "recte illi quidem, sed veluti in vestiendo prius nudum subsignare oportet quem postea vestibus obambiendo involuamus, sic in nudo pingendo prius ossa et musculi disponendi sunt, quos moderatis carnibus et cute ita operias, ut quo sint loco musculi non difficile intelligatur".

104 "La obra está caracterizada por un atento estudio de la anatomía y de las proporciones, con un resultado que logra lo esencial (inspirado en lo antiguo), que exalta la dignidad sublime y armoniosa de la obra. Respecto a la obra de Donatello es más idealizado y mesurado, donde la perfección matemática de las formas es eco de la perfección divina del tema" (cf. De Vecchi y Cerchiari, 1999, p. 66).
} 
straordinaria fatica ${ }^{105}$, para la Iglesia franciscana de la Santa Cruz de Florencia, (figura 34). Así lo reporta G. Vasari (1928), aunque muchos no lo respalden por falta de veracidad histórica:

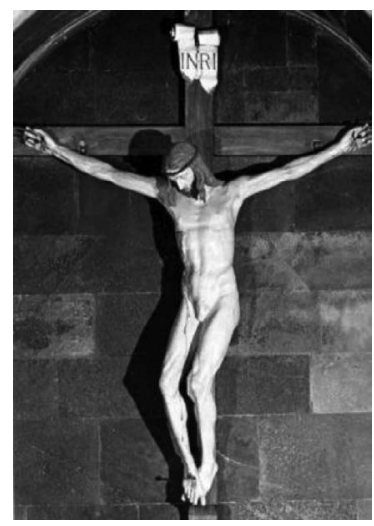

Figura 33. Filippo Brunelleschi.

Crucifijo llamado de los huevos, Iglesia de santa Maria Novella, Florencia, Italia, 1410-1415.

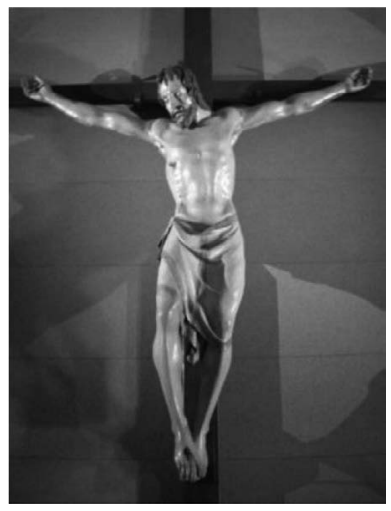

Figura 34. Donatello. Crucifijo, Iglesia de la santa Croce en Florencia, Italia, 1406-1408.

Filippo, que era muy franco, le contestó que, en su opinión, Donato había puesto en la cruz a un campesino, y no a una figura semejante a la de Jesucristo, que era delicadísima y, en todas sus partes, la más perfecta figura de hombre que naciese jamás (1928, p. 770).

105 La representación de este campesino-crucificado, esculpido entre 1406-1408, no carece en absoluto de humanidad ni de realismo, tanto más porque se prestaba a las celebraciones litúrgicas del Viernes Santo cuando se doblaban los brazos para convertirlo en un Cristo yacente. Lo que sucede es que -los criterios estéticos del Renacimiento- sobrevaloran la obra de Brunelleschi, en virtud de la divinización que logra una representación tan real de la anatomía de Cristo (cf. Fantuzzi, 2003, pp. 52-53). 
Como quiera que hayan sucedido las cosas, lo que sí aparece evidente entonces es que la percepción de Brunelleschi tiene todos los síntomas de la armonía de la figura vitruviana más tarde la perfeccionará Leonardo hacia 1490 (figura 35), y en la que se establecerá el paradigma absoluto de todo cuanto pueda expresarse de la anatomía humana ${ }^{106}$ (masculina).

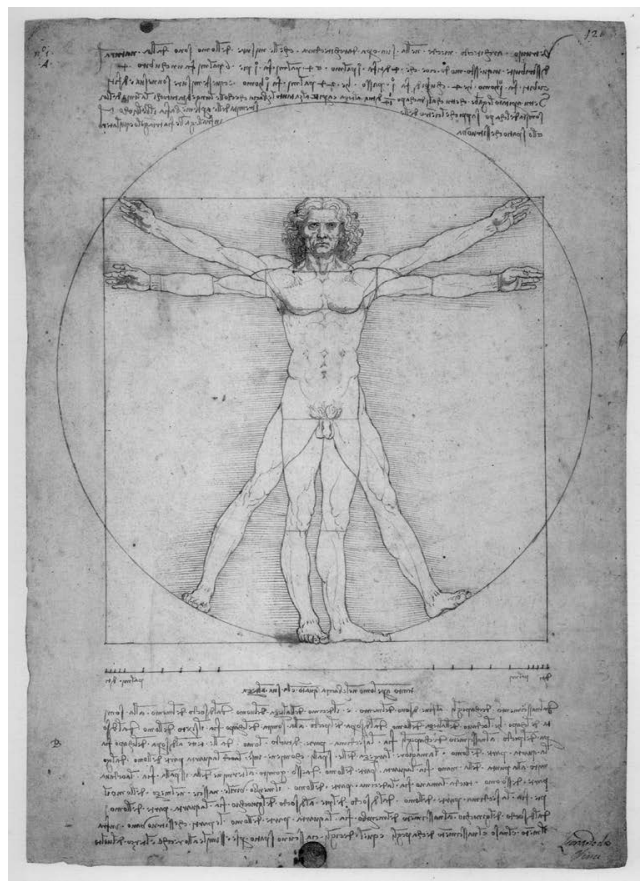

Figura 35. Leonardo da Vinci. L'uomo vitrubiano, Galería de la Academia, Venecia.

Ya habíamos mencionado que la obra escultórica de Nicola Pisano empezaba a recuperar los criterios estéticos del clasicismo grecorromano ${ }^{107}$. Habíamos dicho que hacia el final del Trecento ya se empezaban a aplicar los criterios que florecerían más tarde, en lo que unánimemente se denomina Renacimiento Humanista ${ }^{108}$. En efecto, Brunelleschi adopta el mismo esquema compositivo en los crucifijos de Giotto (figura 22), sin alterar para nada la posición anatómica dejando el esquema ya establecido en el tardo gótico pero, al prestarla en su

106 El primer biógrafo de F. Brunelleschi, A. Manetti, nos asegura que si este logró hacer cuanto hizo no fue solo por haber redescubierto los órdenes clásicos, sino porque "dotado además de buena vista mental (buono occhio mentale), se había familiarizado con la escultura, las dimensiones, las proporciones y la anatomía" (cf. Manetti, 1992, p. 73).

107 "Nicolás Pisano tuvo la fortuna de vivir cuando la escición entre el Medioevo y el Renacimiento humanista no estaba todavía abierta, se encontró en el momento que la expectativa que el reino luminoso, en plena riqueza mística, cuando los valores humanistas de cultura, de ética y la indispensable lógica, se estaban reforzando" (Nicco, 1941, p. 58).

108 "Humanismo y Renacimento representan dos momentos diversos, o dos puntos de vista del mismo momento histórico del cual cada uno pone una característica [...]. Que el Humanismo signifique el renacer de la antigüedad clásica, ese Renacimiento de las artes fundamentalmente" (Nicco, 1941, p. 52). 
escultura, proporcionándole al observador una la visión tridimensional a $180^{\circ}$. Su obra permitía una contemplación tanto más real de este tema, un recorrido que no era posible gozar completamente en pintura, como lo confirma su primer biógrafo: "a juicio de quienes entienden de escultura en el mundo es lo máximo que se pueda expresar de un crucifijo con tanta bondad"109.

No obstante ello, Brunelleschi, que abre las puertas a la escultura renacentista, en esta obra de majestuosa valentía no se atreve en cambio a representar concretamente los genitales del Verbo hecho carne, de Aquel que se hizo semejante en todo a los humanos (Hb. 4:15), de aquel que no tenía por qué diferenciarse del resto de los humanos ${ }^{110}$. Mérito de Cristo -nuevo Adán- fue recuperar la altura de la condición humana caída restaurándola en su inocencia para no avergonzarse del factor sexual que implica su propia humanidad. ¿No hay en esto razón suficiente para hacer del miembro sexual de Cristo, como ocurre con los stigmata, un objeto de ostentatio ${ }^{111}$

Las condiciones tan precisas y sujetas a la verdad y a la naturalidad física de las cosas de lo que no se puede eximir a la anatomía sumado a la talentosa capacidad del tratamiento anatómico que logra Brunelleschi no alcanza a llegar hasta la representación de la genitalidad de Cristo, como una forma más de confesar su Encarnación. Puede que este conflicto explique el hecho de que algunos pintores de fecha avanzada, lo bastante pudorosos como para mantener cubiertas las caderas de Cristo, dejen asomar sin embargo una porción del vello púbico, como queriendo decir que, si ha de haber ocultación de los genitales, al menos se reconozca lo que se oculta (Steinberg, 1989, p. 156). Pero, ¿seguirá cargando el Renacimiento la problemática medieval de abordar con dificultad el tema de la representación de los órganos sexuales de Jesús justo en una época en que será posible hacerlo de modo más audaz? Tal vez sí. "Pudorosamente se nombran los genitales del hombre y de la mujer por medio de eufemismos", escribía san Jerónimo hacia el año $384^{112}$ y así tal vez se sigue pensando durante esta época.

Mucho antes del Molanus, Guillermo Durando, el viejo (ca. 1230-1296), en su famosa obra censuraba a modo de comentario lo que más tarde la Contrarreforma puso en regla completamente. Así lo decía: "los griegos [de rito] se sirven de imágenes, según se afirma, pintándolas solo del ombligo para arriba y no su parte inferior, a fin de eliminar cualquier ocasión de pensamientos vanos"113.

\footnotetext{
109 "Es parecer de los que entienden, que de escultura y maxime de crucifijos no haya nada en el mundo de mayor bondad" (Manetti, 1992, p. 53).

110 "Unde debuit per omnia fratribus similari" Hb. 2:17.

111 "Es evidente que los artistas más conscientes del Renacimiento eligieron obedecer a unos imperativos más profundos que los de la modestia" (cf. Steinberg, 1989, pp. 11, 30-31).

112 "Honeste viri mulierisque genitalia inmutatis sunt appellata nominibus" (San Jerónimo, Epistula ad Eustochium, Paulæ filiam (a una virgen consagrada) 22, 11 PL XXII, 401).

113 Se refiere quizás a la conocida imago pietatis, tal como se la tipificó ya en el siglo XIII. "Græci etiam utuntur [sic] ymaginibus pingentes illas, ut dicitur, solum ab umbilico supra, et non inferius, ut omnis stulte cogitationes occasio tollantur" (Guillelmi Duranti, Rationale divinorum Officiorum, I, 3, 2).
} 
Los Evangelios le han concedido al Verbo de Dios la plena posesión de un cuerpo masculino sin negarle ninguno de sus órganos, pero sin sugerir por ello el ejercicio de la sexualidad puesto que en todo se hizo igual a los hombres a excepción del pecado ${ }^{114}$. Pero, ¿hasta qué punto habría llegado la teología cuando hablaba del cuerpo de Cristo encarnado? Sin embargo, "al igual que en todo arte religioso, también en la madurez del Renacimiento, la divinidad de Cristo no necesitará ser demostrada"; y si hubiera sido preciso argumentarla, las sublimes representaciones de Cristo humanado, son ya "una prueba palpable en la que se puede confirmar la verdad más capital del Credo: el descenso de Dios a la humanidad" (Steinberg, 1989, p. 19). Basta con observar detenidamente el paso gradual que hace este tema del desnudo de Cristo en la cruz, desde cuando la pintura del Tre-Quattrocento italiano representa un simple velo, que no oculta la anatomía, pero sugiere la genitalidad de Cristo, hasta cuando la escultura del Quattro-Cinquecento representa la anatomía completa y la sexualidad íntegra de Jesús en la cruz. El velo trasparente, que no es más que una gasa, no pueden usarse como ropaje materialmente; es una prenda que no significa nada.

Decíamos antes, que esa prenda revela más de lo que vela. Séneca, ya en la antigüedad deploraba prendas como esas por incitadoras y reveladoras de la desnudez corporal ${ }^{115}$, pero que en la iconografía cristiana cobró muchísimo valor cuando la vistió el Mesías en la cruz. El crucifijo desnudo de Brunelleschi inaugura en el Quattrocento la práctica de modelar sobre todo en madera los crucificados, en la entereza de la genitalidad, para ser cubiertos posteriormente por un ceñidor hecho de un tejido de yeso, como lo enseñaba G. Vasari ${ }^{116}$. Algunos escultores del Quattro-Cinquecento se acoplaron a esa práctica ${ }^{117}$, ellos mismos serán los responsables de señalar los parámetros en que se moverá la escultura de este tema de la crucifixión que fortalecerá aún más Miguelángel Buonarroti.

Como es propiamente por el pecado que entró el rubor de estar desnudos por completo, como lo relata el pasaje bíblico del Génesis ${ }^{118}$; por eso mismo, todo lo que implica la condición natural de la corporalidad humana cuando se representa a Cristo de esta manera, se está refiriendo por analogía a la figura de Adán. En este caso el arte cristiano le presta un servicio a la Teología, cuando

114 "Tentatum autem per omnia secundum similitudinem absque peccato" $\mathrm{Hb}$ 4:15.

115 "Veo ueftidos de feda, fi es q fe pued< llamar ueftidos aqllos, en q no ay cofa q defi< da el cuerpo, ni la uergu< ça porq defpues de pueftos, no aura muger que pueda jurar con verdad, q no eftà defnuda" (Séneca, De Beneficiis, VII, 9 , 204-205).

116 En este caso conservamos la integralidad del texto vasariano que dice: "si en realidad los modelos hechos de tierra, o desnudos con paños "entierrados" [con cera o goma] con que se vistan y den la impresión de estar arropados; quedan bien todas estas cosas [esculturas] siendo inmóviles y sin sentimiento, se moverían con gran ligereza, pese a estar quietas, ante quien las modela; lo que no sucede en las cosas vivas pues se mueven" (Vasari, 1971, p. 160). De esto hace citación también L. Steinberg (1989, p. 154).

117 Bastaría mencionar a los más conocidos por sus obras: Michelozzo di Bartolomeo (1396-1472), Desiderio da Settignano (ca. 1430-1464), Andrea del Verrocchio (ca. 1435- 1488), Antonio del Pollaiuolo (ca. 1432-1498), Benedetto da Maiano (1442-1497), I Sangallo: Giuliano (1443-1516), Antonio (1484-1546), Francesco (1484-1576), Baccio da Montelupo (1469-1523) (cf. Lisner, 2000, pp. 38-39).

118 Gn. 3:10-11: "Vocem tuam audivi in paradiso et timui eo quod nudus essem et abscondi me". Cui dixit: "Quis enim indicavit tibi quod nudus esses, nisi quod ex ligno, de quo tibi præceperam, ne comederes, comedisti?". 
el Jardín del Edén y el Monte del Calvario se puede leer complementariamente. En la historia del arte cristiano vendrán posteriormente las representaciones que Miguelángel Buonarroti desarrolló de este tema, en el que por la forma y por el trato de la figura humana queda vencido el pudor y se hace igualmente evidente la verdad por la que el hombre es imaginem et similitudinem Dei.

\section{Referencias}

Arellano, I., y Duarte, J. (2003). El auto sacramental. Madrid: Del Laberinto.

Bastús, J. (1862). El Trivio y el Cuadrivio o la nueva enciclopedia: el cómo, el cuándo y la razón de las cosas. Barcelona: s.n.

Beigbeder, O. (1995). Léxico de los símbolos. Madrid: Encuentro.

Bellosi, 1., Cavazzini, 1., y Galli, A. (2002). Masaccio e le origini del Rinascimento. Catalogo della mostra Ginevra - Milano (20 set-21 dic). Milano: Skira.

Belting, H. (2007). La vera immagine di Cristo. Torino: Bollati Boringhieri.

Belting, H. (2009). Imagen y Culto: una historia de la imagen anterior a la era del arte. Madrid: Akal.

Bisconti, F. (2009, 6 april). Crocifissione e Risurrezione nell'arte cristiana delle origini; il patibolo e la tomba vuota. L'Osservatore Romano.

Bonfante, L. (2003). Perizoma and Belts. Etruscan dress. Baltimore: The Johns Hopkins University press.

Borgia, E. (1779). De cruce Vaticana ex dono Iustini Augusti in parasceve maioris hebdomadae publicae venerationi exhiberi solita. Roma: Tipografía de la Sagrada Congregación.

Brigida di Svezia. (1982). Relevationes. Scelta antologica da Le Revelationi. Roma: Tipografia Poliglotta Vaticana.

Cantalamessa, R. (1972). I più antichi testi pasquali della Chiesa. Roma: Edizioni Liturgiche.

Carletti, C. (2010, 14 april). Il graffito blasfemo del Palatino e un carme di Giovanni Pascoli: Alessameno a Zvani. L'Osservatore Romano. 
Carletti, C. (2009, 20 noviembre). La croce nella documentazione epigráfica. L'Osservatore Romano.

Carletti, C. (2008). Epigrafia dei cristiani in occidente dal III al VII secolo. Bari: Edipuglia.

Cellucci, L. (1938). Le "Meditationes vitx Christi" e i poemetti che ne furono ispirati. Firenze: Leo S. Olshki.

Chevalier J., y Gheerbrant, A. (2000). Velo. Diccionario de los símbolos. Barcelona: Herder, 1107.

Cirlot, J. E. (2008). Diccionario de símbolos (13a ed.). Barcelona: Siruela.

Clark, K. (2008). El desnudo: un estudio de la forma ideal (7a ed.). Madrid: Alianza forma.

Conti, R. (1990). Ampolle di Terra Santa, schede n. 50-51. Splendori di Bisanzio (Catalogo della mostra), Ravenna, 137-139.

Craveri, M. (2005). I Vangeli apocrifi. Torino: Einaudi.

Danielou J., y Marrou, I. (1982). Nueva historia de la Iglesia, I. Madrid: Cristiandad.

De La Vorágine, S. (1982). La leyenda dorada. Madrid: Alianza.

De Lavalle, J. A. (1991). Escultura en el Perú. Lima: Ausonia.

De Santos Otero, A. (1991). Los evangelios apócrifos. Madrid: BAC.

De Vecchi, P., y Cerchiari, E. (1999). I tempi dell'arte, II. Milano: Bompiani.

Denzinger, H. (d.z). Enchiridion Symbolorum: definitionum et declarationum de rebus fidei et morum.

Di Berardino, A. (2007). Nudità Battesimale. A. Di Bernardino (ed.). Nuovo Dizionario Patristico e di Antichità cristiane (2a ed.), (2), 3.568. Genova: Marietti.

Duchesne, L. (1955). Le Liber Pontificalis: texte, introduction et commentaire, I. Paris: E. De Boccard.

Emmerick, A. C. (2005). La dolorosa passione de nostro Signore Gesù Cristo secondo le visioni della Beata Anna Katharina Emmerick. Camerata Picena: Shalom.

Fantuzzi, V. (2003). Immagini del redentore. La Civiltà Cattolica, 3667, 49-62. 
Felle, A. E. (2000). Croce (Crocefissione). Bisconti, F., ed. Temi di iconografia paleocristiana, 158-162. Città del Vaticano: Libreria Editrice Vaticana.

Fossi, G. (1999). Fra il cielo e la terra: Armonie celesti e "mirabili difformità" del corpo medievale. en G. Fossi (ed.). Il nudo nell'arte: eros, natura, artificio, 42-76. Firenze: Giunti.

Franco, Á. (1991). El tesoro de san Isidoro y la monarquía leonesa. Boletín del Museo Arqueológico Nacional, 9, 35-68.

García, R. (1956). Rasgos característicos de la "Devotio Moderna”. Manresa, 28,317 .

Gardin, J. B. (1825). Latin synonyms, with their different significations: and examples taken from the best latin authors. London: J. M. Gosset.

Garrucci, R. (1856). Un graffito blasfemo nei palazzo dei cesari. La Civiltà Cattolica, 3, 529-547.

Gero, S. (1973). The Libri Carolini and the Image Controversy. Greek Orthodox Theological Review, 18, 7-34.

Giglioni, P. (2000). La Croce e il Crocifisso nella tradizione e nel arte. Città del Vaticano: Libreria Editrice Vaticana.

Giuliani, R. (2000). Atleta. Bisconti, F. (ed.). Temi di iconografia paleocristiana, 131132. Città del Vaticano: Libreria Editrice Vaticana.

González, F. (1959). Libro de los viajes o de las presencias. Medellín: Aguirre.

Gough, M. (1973). The Origins of Christian Art. London: Thames and Hudson.

Grabar, A. (1967). L'arte paleocristiana. Milano: Rizzoli.

Grabar, A. (2003). Las vías de la creación en la iconografía cristiana. Madrid: Alianza Forma.

Grabar, A. (2007). Los orígenes de la estética medieval. Madrid: Siruela.

Grondijs, L. H. (1947). L'iconographie byzantine du crucifié mort sur la croix. Bruxelles: Byzantion.

Grossi, V. (2006). Croce, Crocifissione. A. Di Bernardino (ed.). Nuovo Dizionario Patristico e di Antichità cristiane, 1, 1.295-1.298. Genova: Marietti.

Heid, S. (2006). Athleta Christi. Di Bernardino, A. (ed.). Nuovo Dizionario Patristico e di Antichità cristiane, 1, 645-646. Genova: Marietti. 
Ibáñez, J., y Mendoza, F. (1975). Melitón de Sardes: Homilía sobre la pascua. Pamplona: Universidad de Navarra, S. A.

Jászai, G. (1991- 2002). Crocifisso. Enciclopedia dell'arte medievale, 5, 577-586. Roma: Istituto della Enciclopedia italiana, Giovanni Treccani.

Jedin, H. (1970). Manual de historia de la Iglesia: de la Iglesia primitiva edad media a la reforma gregoriana, 3. Barcelona: Herder.

Kitzinger, E. (2005). Arte Altomedievale. Torino: Giulio Einaudi.

Le Goff, J. (2005). Il corpo nel Medioevo. Bari: Laterza.

Leclercq, H. (1907-1953). Croix et Crucifix. F. Cabrol y H. Leclercq (eds.). Dictionnaire d'Archéologie chrétienne et de liturgie, 3, 1.907-1.953; 3.045-3.131. París: Letouzey.

Leloir, M. (1951). Dictionnaire du costume et des accessoires des armes et des étoffes des origines à nos jours. Paris: Librairie Gründ.

Lisner, M. (2000). Il crocifisso ligneo di Michelangelo per il vecchio coro della chiesa di Santo Spirito a Firenze: The wooden crucifix of Michelangelo for the old choir of the Church of Santo Spirito of Florence. Comune di Firenze-assessorato alla cultura (ed.). Il crocifisso di Santo Spirito: The Crucifix of Santo Spirito, 31-68. Firenze: Comune de Firenze.

Mâle, É. (2001). El arte religioso de la Contrarreforma: estudios sobre la iconografía del final del siglo XVI y de los siglos XVI y XVIII. Madrid: Encuentro.

Manetti, A. (1992). Vita di Filippo Brunelleschi. Perrone, C. (ed.). Roma: Salerno.

Mathews, T. F. (2000). La nudità nel cristianesimo. S. Ensoli, y E. La Rocca (eds.). Aurea Roma: dalla città pagana alla città cristiana, 396-397. Roma: L'Erma di Bretschneider.

Mellado, F. (1852). Diccionario Universal de Literatura, Ciencias, Artes, Agricultura, Industria y Comercio. Madrid: Establecimiento tipográfico de Mellado.

Menestò, E., et al. (eds.). (1995). Fontes Francescani. Assisi: Porziuncula.

Nicco, G. (1941). Nicola Pisano: orientamenti sulla formazione del gusto italiano. Roma: Palombi.

Panofsky, E. (2006). Renacimiento y renacimientos en el arte occidental. (3a ed.). Madrid: Alianza Editorial. 
Pásztor, E. (2000). Donne e sante: studi sulla religiosità femminile nel Medio Evo. Roma: Edizioni Studium.

Pijoán, J. (1966). El arte románico siglos XI y XII. Summa Artis: historia general del arte, IX. Madrid: Espasa-Calpe.

Plazaola, J. (2001). Arte e Iglesia: veinte siglos de arquitectura y pintura cristiana. Guipúzcoa: Nerea.

Réau, L. (2000). Iconografía del arte cristiano: iconografía de la Biblia, Nuevo testamento, T. I, II. (2a ed.). Barcelona: Serbal.

Revilla, F. (2007). Diccionario de iconografía y simbología. (5a ed.). Madrid: Cátedra.

Romanini, A. M. (2007). L'arte medievale in Italia, Milano: Sansoni Editore.

Sacco, G. (1997). Il graffito blasfemo del Pædagogium nella Domus Augustana del Palatino. I. Di Stefano Manzella (ed.). Le iscrizioni dei Cristiani in Vaticano. Materiali e contributi per una mostra epigrafica, 193-194. Città del Vaticano: Libreria Editrice Vaticana.

Schönborn, C. (1999). El icono de Cristo. Madrid: Encuentro.

Sebastián, S. (2009). Mensaje simbólico del arte medieval: arquitectura, liturgia e iconografía. Madrid: Encuentro.

Spier, J. (2007). Late antique and early christian gems. Wiesbaden: Reichert.

Steinberg, L. (1989). La sexualidad de Cristo: en el arte del Renacimiento y en el olvido moderno, traducción de Jesús Valiente Maya (2a ed.). Madrid: Hermann Blume.

Thoby, P. (1963). Le crucifix des origines au concile de Trente: supplément. Nantes: A. Bellanger.

Thoby, P. (1959). Le crucifix des origines au concile de Trente. Nantes: A. Bellanger.

Thode, H. (1993). Francesco d'Assisi e le origini dell'arte del Rinascimento in Italia. Roma: Donzelli.

Toscano, G. M. (1960). Il pensiero cristiano nell'arte, III. Bergamo: Istituto d'arti grafiche.

Van Laarhoven, J. (1999). Storia dell'arte cristiana. Milano: Bruno Mondadori.

Vasari, G. (1928 versión). Le vite de' più eccellenti pittori, scultori et architettori, I-III. Milano: Sonzogno. 
Vasari, G. (1791). Introduzione di M. Giorgio Vasari pittore aretino alle tre Arti del disegno cioè architettura scultura e pittura. Siena: Pazzini, C e Compagno.

Verdon, T. (2009). Il catechismo della carne: corporeità e arte cristiana. Siena: Cantagalli.

Viladesau, R. (2006). The Beauty of the cross: The passion of Christ in theology and the arts from the catacombs to the eve of the Renaissance. New York: Oxford University Press.

Wessel, K. (1967). Der nackte crucifixus von Narbonne. Rivista di archeologia Cristiana, 43, 333-345.

Yates, J. (1875). Tunica. Dictionary of Greek and Roman Antiquities, 1. 173-1.174. London: John Murray.

Zorzi, M. B. (2007b). Desiderio della Bellezza (eros tou kalou) da Platone a Gregorio di Nissa. Tracce di una rifrazione teologico semantica. Studia Anselmiana, 145.

Zorzi, M. B. (2007a) Un messia senza bellezza: (quasi una) storia dell'interpretazione patristica di Is 53,2-3 dalle origini a Celso. M. B. Zorzi. Desiderio della Bellezza (eros tou kalou) da Platone a Gregorio di Nissa. Tracce di una rifrazione teologico semantica. Studia Anselmiana, 145. 